\title{
Relationship between bend-faulting at trenches and intermediate-depth seismicity
}

\author{
César R. Ranero \\ IFM-GEOMAR and SFB754, Wischhofstrasse 1-3, D-24148 Kiel, Germany
}

Now at ICREA at Instituto de Ciencias del Mar, CSIC, Pg. Maritim de la Barceloneta 37-49, E-08003 Barcelona, Spain (cranero@icm.csic.es)

\section{Antonio Villaseñor}

Institute of Earth Sciences "Jaume Almera," CSIC, Lluis Solé i Sabarís s/n, E-08028 Barcelona, Spain

\section{Jason Phipps Morgan}

Department of Geological Sciences, Cornell University, EAS 4164 Snee Hall, Ithaca, New York 14853, USA

\author{
Wilhelm Weinrebe \\ IFM-GEOMAR and SFB754, Wischhofstrasse 1-3, D-24148 Kiel, Germany
}

[1] We have studied faulting associated with bending of the incoming oceanic plate along segments of Middle America and Chile subduction zones and its relationship to intermediate-depth intraslab seismicity and slab geometry. Multibeam bathymetry shows that bending-related faulting forms patterns made of sets of faults with orientations ranging from parallel to almost perpendicular to the trench axis. These fault patterns may change along a single subduction zone within along-strike distances of several hundred kilometers or less. Where available, near-trench intraplate earthquakes show normal-fault focal mechanisms consistent with mapped bending-related normal faults. The strike of bending-related faults in the incoming oceanic plate is remarkably similar to the strike of the nodal planes of intermediate-depth earthquakes for each segment of the study areas. This similarity in strike is observed even for faults oriented very oblique to the trench and slab strikes. Thus, in the studied subduction zones, results strongly support that many intraslab earthquakes do not occur along the planes of maximum shear within the slab and that much intermediate-depth seismicity occurs by reactivation of faults formed by plate bending near the trench. Furthermore, a qualitative relationship between trench faulting and intraslab seismicity is indicated by segments of the incoming plate with pervasive bend-faulting that correspond to segments of the slabs with higher intermediate-depth seismicity.

Components: 13,214 words, 13 figures, 3 tables.

Keywords: Subduction zones; plate bending and faulting; intermediate-depth seismicity.

Index Terms: 8150 Tectonophysics: Plate boundary: general (3040); 7230 Seismology: Seismicity and tectonics (1207, 1217, 1240, 1242); 7218 Seismology: Lithosphere (1236); 8010 Structural Geology: Fractures and faults; 3045 Marine Geology and Geophysics: Seafloor morphology, geology, and geophysics.

Received 11 April 2005; Revised 23 August 2005; Accepted 30 September 2005; Published 13 December 2005.

Ranero, C. R., A. Villaseñor, J. Phipps Morgan, and W. Weinrebe (2005), Relationship between bend-faulting at trenches and intermediate-depth seismicity, Geochem. Geophys. Geosyst., 6, Q12002, doi:10.1029/2005GC000997. 


\section{Introduction}

[2] Subduction zones are commonly characterized by well defined inclined Wadati-Benioff seismic zones that can reach depths up to $500-670 \mathrm{~km}$ [Frohlich, 1989]. Seismicity in subduction zones is usually referred to as shallow $(<70 \mathrm{~km})$, intermediate-depth $(70-350 \mathrm{~km})$, or deep-focus $(>350 \mathrm{~km})$. Intermediate and deep seismicity is believed to occur in the cold parts of subducting slabs. However, the occurrence of earthquakes at depths $>30 \mathrm{~km}$ is perplexing because there high confining pressure should inhibit brittle failure. A commonly invoked possible mechanism to overcome this is dehydration embrittlement [Raleigh and Paterson, 1965; Meade and Jeanloz, 1991; Hacker et al., 2003]. During progressive metamorphic dehydration of the slab, fluids contained in hydrous phases are released leading to increased pore pressure and decreased effective confining pressure, thereby promoting seismic rupture. The tectonic setting where most of the hydration of the oceanic plate occurs is still in debate and several possibilities have been suggested: near spreading centers [Peacock, 1990; Kirby et al., 1996; Staudigel et al., 1996], intraplate by fluids rising from underlying mantle plumes [Seno and Yamanaka, 1996], or during bending near the trench, in the crust and upper few kilometers of the mantle [Kirby et al., 1996], or also deeper, $15-30 \mathrm{~km}$ into the mantle [Peacock, 2001; Ranero et al., 2003a; Ranero and Sallares, 2004]. Depending where hydration has occurred, intermediate-depth earthquakes might nucleate by dehydration embrittlement across the slab [Meade and Jeanloz, 1991] or alternatively could selectively reactivate old faults formed on the oceanic plate during bending at the outer-rise/ trench prior to subduction [Savage, 1969; Kirby et al., 1996; Jiao et al., 2000; Peacock, 2001]. This latter interpretation implies that bending-related faults are structures cutting through the crust and mantle that have been extensively hydrated by water percolation and mineral alteration in the outer rise-trench region. Jiao et al. [2000] showed that the similarity of fault plane solutions of outer rise and intermediate-depth seismicity in Tonga and Kurile trenches supports the fault reactivation hypothesis. In contrast, Christova and Scholz's [2003] study of the Vanuatu subduction zone supports the formation of new faults for some events, but also that there is fault reactivation. In support, Brudzinski and Chen's [2005] study of seismicity in subhorizontal slabs concludes that there is no obvious preferred orientation of fault plane solu- tions and that the earthquakes are probably not caused by reactivation of preexisting faults.

\section{Strategy of the Analysis}

[3] Jiao et al. [2000] in Tonga, and Christova and Scholz [2003] in Vanuatu subduction zones, compared the structure inferred from intermediatedepth seismicity within the slab with intraplate seismicity in the outer rise of the plate descending at the trench. Brudzinski and Chen [2005] study intraslab seismicity from Vanuatu, Tonga and PeruChile subduction zones. In these studies, direct comparison with the actual fault pattern at the trench was not possible due to the lack of highresolution bathymetric maps of the incoming plate. The comparison of a large number of intraplate events from the trench area with intermediate-depth seismicity cannot be carried out at many subduction zones because instrumentally recorded intraplate trench seismicity is scarce or absent. However, in these areas, fault-relief observed on the trench seafloor preserves a record of faulting even when recorded earthquake activity is lacking. Furthermore, triggering of near-trench bendingrelated events may be influenced by stress changes after large interplate thrust earthquakes [e.g., Mikumo et al., 2002] so that the existing earthquake record may not be representative of the entire fault structure formed during bending of the oceanic plate.

[4] We have analyzed high-resolution multibeam bathymetry data along several oceanic trenches to constrain the fault structure of incoming plates. Recent seafloor mapping along the Central America (off Costa Rica, Nicaragua [Ranero et al., 2003a]; El Salvador and Guatemala [Ranero et al., 2003b]) and South America (off Chile from $20^{\circ}-24^{\circ} \mathrm{S}$ [von Huene and Ranero, 2003] and $28^{\circ}-34^{\circ} \mathrm{S}$ [Weinrebe et al., 2003]) subduction zones has collected enough bathymetric coverage to investigate the relationship between bendingrelated faults and intraslab seismicity (Figure 1). Also, we have mapped the structure of the corresponding subducted slabs, and analyzed the focal mechanisms of their intraslab earthquakes. Finally we have compared the fault patterns of the incoming plate to the structure and seismicity of the corresponding subducting slab.

[5] High-resolution bathymetry shows that, as the oceanic plate bends into the subduction zone, a widespread system of extensional faulting develops between the outer rise and the trench axis. Studied 

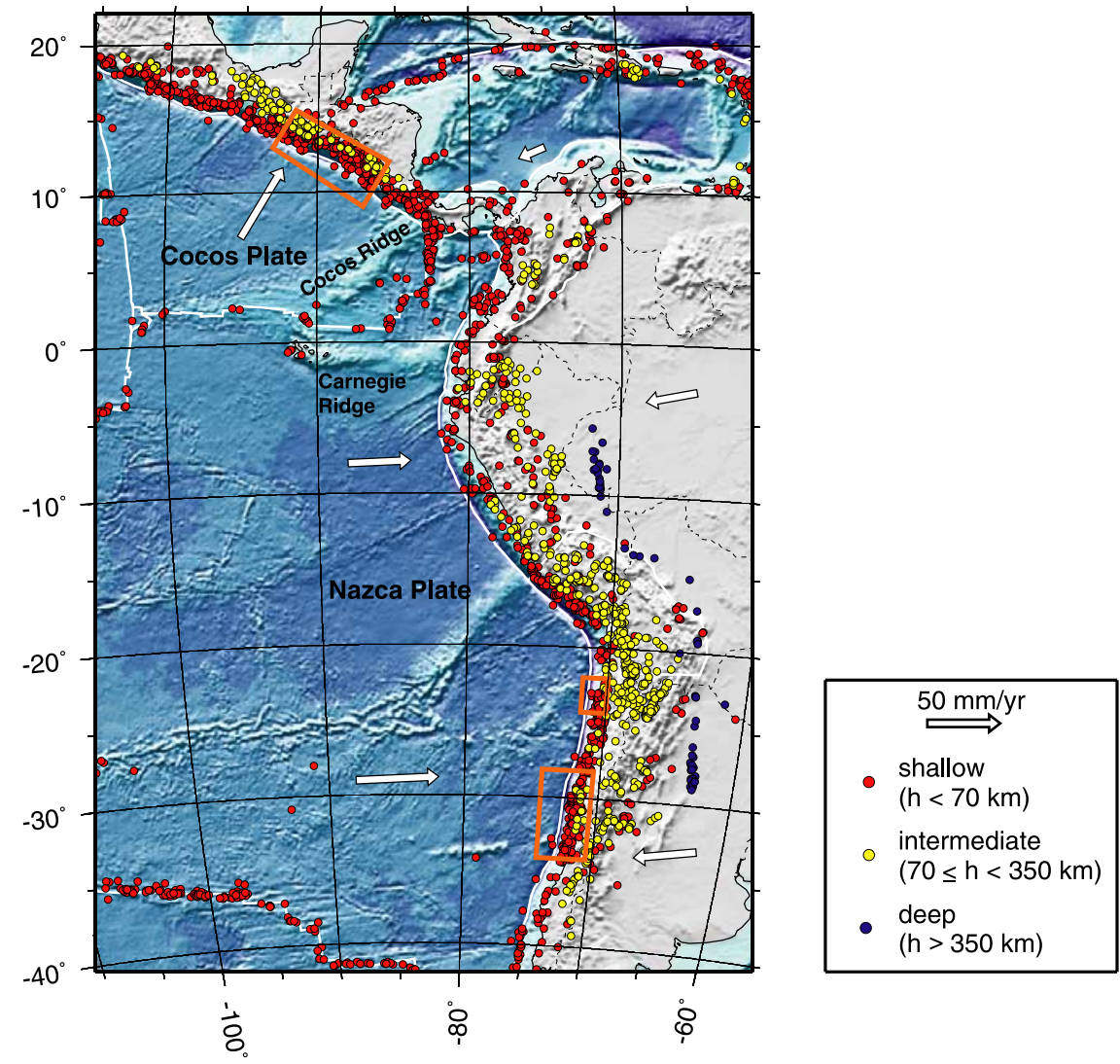

Figure 1. Shaded relief map showing Nazca and Cocos plates subducting underneath South America and Middle America, respectively. Filled circles denote earthquakes color-coded to depth. Arrows indicate absolute plate motions in the hot spot reference frame [Gripp and Gordon, 1990]. Boxes mark areas with multibeam bathymetry coverage of the oceanic plate at the trench, shown in Figures 3, 6, and 7.

subduction zones have regions with different faultstrike patterns that can be directly compared to the nodal planes of the downdip corresponding intraslab earthquakes.

[6] We have compared the strike and dip of trenchfault populations with the geometry of the slab and the nodal planes of intraslab earthquakes using a relocated global earthquake catalog [Engdahl et al., 1998] and focal mechanisms from the Harvard CMT catalog [Dziewonski et al., 1981; Dziewonski and Woodhouse, 1983]. From the complete CMT catalog for 1977-2004 we have selected wellconstrained focal mechanisms using the criteria of Frohlich and Davis [1999], resulting in nodal plane angles with uncertainties of 5-10 degrees or less (see Appendix A for details on the selection criteria). Slab geometries were mapped using a combination of global tomographic images, global and local seismicity. Within the resolution of the earthquake locations and tomographic models, results support that intermediate-depth seismicity occurs within the slab. Nodal planes of intraslab earthquakes have been rotated using an Euler angle based on the local slab dip at the earthquake location in order to compare them with the fault structure of the incoming oceanic plate, following the approach of Jiao et al. [2000]. See appendix A and $\mathrm{B}$ for detailed descriptions of the data sets and methodology.

[7] We have used Fisher statistics [Fisher, 1953] to determine mean directions and uncertainties of the distribution of the of nodal plane poles (for a more detailed description of the statistical parameters see Appendix B). Average strike and dip of the nodal planes of each of those clusters has been compared to average strike and dip of bend-faults mapped at the corresponding incoming plate (Tables $1-3$ ).

[8] To test the hypothesis of fault reactivation, we selected areas where fault patterns in the incoming oceanic plate clearly differ from the orientation expected for the formation of new faults predicted by the state of stress of the corresponding slabs. Along much of Middle America the incoming oceanic plate has one dominant set of bend-faults with a nearly constant azimuth for $\sim 1000 \mathrm{~km}$ 
Table 1. Middle America: Mean Directions, Uncertainties, and Statistical Parameters for Trench and Slab Segment, Outer-Rise Faults, and Rotated Intraslab Earthquakes ${ }^{\mathrm{a}}$

\begin{tabular}{|c|c|c|c|c|c|c|c|c|c|}
\hline \multirow[b]{2}{*}{ Region } & \multirow[b]{2}{*}{ Figure } & \multicolumn{2}{|c|}{ Fault Pole ${ }^{b}$} & \multicolumn{2}{|c|}{ Fault Plane } & \multirow[b]{2}{*}{ Error, $^{\mathrm{c}}$ deg } & \multirow[b]{2}{*}{$\mathrm{N}$} & \multirow[b]{2}{*}{$\mathrm{R}$} & \multirow[b]{2}{*}{$\kappa$} \\
\hline & & Azimuth, deg & Plunge, deg & Strike, deg & Dip, deg & & & & \\
\hline \multicolumn{10}{|c|}{ Trench and Slab Segments } \\
\hline Nicaragua-Costa Rica & 3 & 228 & - & 318 & $\sim 45^{\mathrm{d}}$ & 2 & - & - & - \\
\hline Guatemala-El Salvador & 3 & 204 & - & 294 & - & 3 & - & - & - \\
\hline \multicolumn{10}{|c|}{ Trench Faults } \\
\hline Nicaragua-Costa Rica (S4a) & 3 & 228 & - & 318 & - & 12 & - & - & - \\
\hline Guatemala-El Salvador (S4b) & 3 & 230 & - & 320 & - & 7 & - & - & - \\
\hline Joint (S4a and S4b) & 3 & 229 & - & 319 & - & 9 & - & - & - \\
\hline \multicolumn{10}{|c|}{ Outer Rise Earthquakes } \\
\hline NE poles (S4a and S4b) & $5 b$ & 33 & 45 & 123 & 46 & 8 & 11 & 10.7 & 31.9 \\
\hline $\mathrm{SW}$ poles (S4a and $\mathrm{S} 4 \mathrm{~b})$ & $5 b$ & 216 & 45 & 306 & 45 & 10 & 11 & 10.5 & 21.8 \\
\hline \multicolumn{10}{|c|}{ Rotated Intraslab Earthquakes } \\
\hline NE poles $(\mathrm{S} 4 \mathrm{a})$ & $5 \mathrm{~d}$ & 62 & 42 & 152 & 48 & 18 & 4 & 3.9 & 26.1 \\
\hline NE poles (S4b) & $5 \mathrm{~d}$ & 37 & 45 & 127 & 45 & 9 & 21 & 19.5 & 13.6 \\
\hline SW poles $(\mathrm{S} 4 \mathrm{a})$ & $5 \mathrm{~d}$ & 233 & 47 & 323 & 44 & 20 & 4 & 3.9 & 21.3 \\
\hline SW poles (S4b) & $5 \mathrm{~d}$ & 230 & 43 & 320 & 47 & 7 & 21 & 20.1 & 22.5 \\
\hline
\end{tabular}

\footnotetext{
${ }^{\mathrm{a}} N$, number of poles or faults used to obtain the mean direction; $R$, randomness parameter (for less scattered distributions, randomness should approach $N$ ); $\kappa$, precision parameter (larger values indicate tighter clustering).

${ }^{b}$ To facilitate the comparison between fault parameters (strike and dip) and nodal plane parameters (azimuth and plunge of poles), for each distribution of faults and nodal planes the table displays both the azimuth and plunge of the mean fault/plane pole and the strike and dip of the mean fault $/$ plane itself.

${ }^{c}$ When only the fault strike is available, the error estimate is the standard deviation. When both strike and dip are available, the error estimate is the parameter $\alpha_{95}$ for Fisher's statistics (see Appendix B).

${ }^{\mathrm{d}}$ Fault dip obtained from seismic images.
}

along the trench, whereas the subducting slab is segmented in two areas with strikes differing by $\sim 25^{\circ}$. In north Chile two sets of faults strike parallel and highly oblique to the trench direction, respectively, while a steep slab strikes with a constant azimuth. In central Chile faults strike subparallel and highly oblique to the trench direction, and the corresponding slab displays a very shallow dip angle. We determined the principal stress orientations in the slabs of the study regions

Table 2. Northern Chile: Mean Directions, Uncertainties, and Statistical Parameters for Outer-Rise Faults and Rotated Intraslab Earthquakes ${ }^{\mathrm{a}}$

\begin{tabular}{|c|c|c|c|c|c|c|c|c|c|}
\hline \multirow[b]{2}{*}{ Region } & \multirow[b]{2}{*}{ Figure } & \multicolumn{2}{|c|}{ Fault Pole } & \multicolumn{2}{|c|}{ Fault Plane } & \multirow[b]{2}{*}{ Error, deg } & \multirow[b]{2}{*}{$N$} & \multirow[b]{2}{*}{$R$} & \multirow[b]{2}{*}{$\kappa$} \\
\hline & & Azimuth, deg & Plunge, deg & Strike, deg & Dip, deg & & & & \\
\hline \multicolumn{10}{|c|}{ Trench Faults } \\
\hline F1 trench faults & 6 & 279 & - & 9 & - & 15 & - & - & - \\
\hline F2 trench faults & 6 & 231 & - & 321 & - & 3 & - & - & - \\
\hline \multicolumn{10}{|c|}{ Rotated Intraslab Earthquakes: $70-160 \mathrm{~km}$} \\
\hline W group 1 (red) & $9 \mathrm{c}$ & 282 & 40 & 12 & 50 & 9 & 14 & 13.4 & 22.4 \\
\hline W group 2 (blue) & $9 \mathrm{c}$ & 235 & 46 & 325 & 44 & 5 & 28 & 27 & 26.6 \\
\hline W joint (red and blue) & $9 \mathrm{c}$ & 251 & 46 & 341 & 44 & 6 & 42 & 38.8 & 12.8 \\
\hline E joint (red and blue) & $9 \mathrm{c}$ & 86 & 43 & 176 & 47 & 5 & 42 & 40.1 & 21.1 \\
\hline \multicolumn{10}{|c|}{ Rotated Intraslab Earthquakes: $160-360 \mathrm{~km}$} \\
\hline W poles & $9 \mathrm{c}$ & 260 & 46 & 350 & 44 & 7 & 42 & 38.4 & 11.5 \\
\hline E poles & $9 \mathrm{c}$ & 102 & 43 & 192 & 47 & 5 & 42 & 40.0 & 20.8 \\
\hline
\end{tabular}

\footnotetext{
${ }^{\mathrm{a}}$ For an explanation of the parameters, see Table 1 and Appendix B.
} 
Table 3. Central Chile: Mean Directions, Uncertainties, and Statistical Parameters for Outer-Rise Faults and Rotated Intraslab Earthquakes ${ }^{\mathrm{a}}$

\begin{tabular}{|c|c|c|c|c|c|c|c|c|c|}
\hline \multirow[b]{2}{*}{ Region } & \multirow[b]{2}{*}{ Figure } & \multicolumn{2}{|c|}{ Fault Pole } & \multicolumn{2}{|c|}{ Fault Plane } & \multirow[b]{2}{*}{ Error, deg } & \multirow[b]{2}{*}{$N$} & \multirow[b]{2}{*}{$R$} & \multirow[b]{2}{*}{$\kappa$} \\
\hline & & Azimuth, deg & Plunge, deg & Strike, deg & Dip deg & & & & \\
\hline \multicolumn{10}{|c|}{ Flat-slab cluster at $28.5 \mathrm{~S}, 69 \mathrm{~W}$} \\
\hline \multicolumn{10}{|c|}{ Trench Faults } \\
\hline F1 trench faults & 7 & 293 & - & 23 & - & 12 & - & - & - \\
\hline F2 trench faults & 7 & 234 & - & 324 & - & 11 & - & - & - \\
\hline \multicolumn{10}{|c|}{ Intraslab Earthquakes } \\
\hline NE poles & $11 \mathrm{a}$ & 54 & 30 & 144 & 60 & 20 & 5 & 4.7 & 15.9 \\
\hline SW poles & $11 \mathrm{a}$ & 234 & 61 & 324 & 30 & 9 & 5 & 4.9 & 71.3 \\
\hline \multicolumn{10}{|c|}{$\begin{array}{c}\text { Flat-slab earthquakes in the continuation of the Juan Fernández Ridge } \\
\text { Trench Faults }\end{array}$} \\
\hline F3 trench faults & 7 & 278 & - & 8 & - & 16 & - & - & - \\
\hline F4 trench faults & 7 & 324 & - & 54 & - & 7 & - & - & - \\
\hline \multicolumn{10}{|c|}{ Intraslab Earthquakes } \\
\hline SE poles & $11 b$ & 110 & 48 & 200 & 42 & 14 & 13 & 11.7 & 9.5 \\
\hline NW poles & $11 b$ & 302 & 42 & 32 & 48 & 10 & 13 & 12.4 & 18.5 \\
\hline
\end{tabular}

${ }^{\mathrm{a}}$ For an explanation of the parameters, see Table 1 and Appendix B.

using the mapped geometry of the slab and the intermediate-depth earthquakes of the CMT catalog similarly to the approach of Chen et al. [2004]. Projecting the $\mathrm{P}$ and $\mathrm{T}$ axes of the local CMT catalog along the local dip of the slab for Middle America and north Chile shows that the principal compressional and tensional stresses are oriented roughly perpendicular and parallel to the slab dip, respectively, and that the slabs are in downdip tension (Figure 2). In central Chile, where the slab dips gently for several hundreds of kilometers from $\sim 100-125 \mathrm{~km}$ depth, the principal compressional and tensional stresses are similarly perpendicular and parallel to the slab geometry, respectively. Thus all selected slabs are appropriate for studying the relationship between intraslab seismicity and fault reactivation.

\section{Middle America}

[9] Along the Middle America Trench (MAT) the Cocos plate subducts beneath the Caribbean plate at $\sim 9 \mathrm{~cm} / \mathrm{yr}$ with a roughly trench normal convergence vector (Figure 1). We have mapped faults of the oceanic plate, mapped the top of the slab, and analyzed outer rise and intraslab seismicity along $\sim 1200 \mathrm{~km}$ of the Middle America subduction zone (Figure 1).

\subsection{Incoming Plate Structure}

[10] The incoming Cocos plate was formed at two spreading centers and modified in some regions by Galapagos hot spot magmatism, resulting in the four segments subducting along the study area (Figure 3). Segments 1-3 were formed at the Cocos-Nazca spreading center, and segment 4 at the East Pacific Rise. Segment 1 spans the Cocos Ridge formed by hot spot magmatism (Figures 1 and 3a). Here the crust is thick [Walther, 2003] and bends little into the subduction zone. Large fault blocks perpendicular to the trench are partially filled with undisturbed sediment [von Huene et $a l ., 2000]$ indicating that faulting is old and not related to plate bending. Segment 2 is partially covered by large seamounts formed by hot spot magmatism [Werner et al., 1999]. Here the plate bends more than at segment 1 and a narrow area of bend-faulting reactivates the spreading fabric (Figure 3a). At segment 3 magnetic lineations strike perpendicular to the trench [Barckhausen et al., 2001], the plate bends less than to the NW and $\mathrm{SE}$ and a few trench-parallel faults form normal to the magnetic lineations creating a new fabric.

[11] Segment 4 is located north of a small trenchperpendicular ridge that marks the boundary between lithosphere formed at the Cocos-Nazca spreading center and East Pacific Rise. Here, the crust is $\sim 5 \mathrm{~km}$ thick [Walther et al., 2000] and bend-faulting reactivates the fabric parallel to the magnetic lineations across the broadest area in the region. Faults are parallel to the trench direction along segment $\mathrm{S} 4 \mathrm{a}$ and $\sim 25^{\circ}$ oblique along segment S4b (Figure 3). Faulting forms dominantly half grabens with fault scarps facing landward. Seismic reflection data images faults cutting to at least $20 \mathrm{~km}$ into the plate [Ranero et al., 2003a]. 

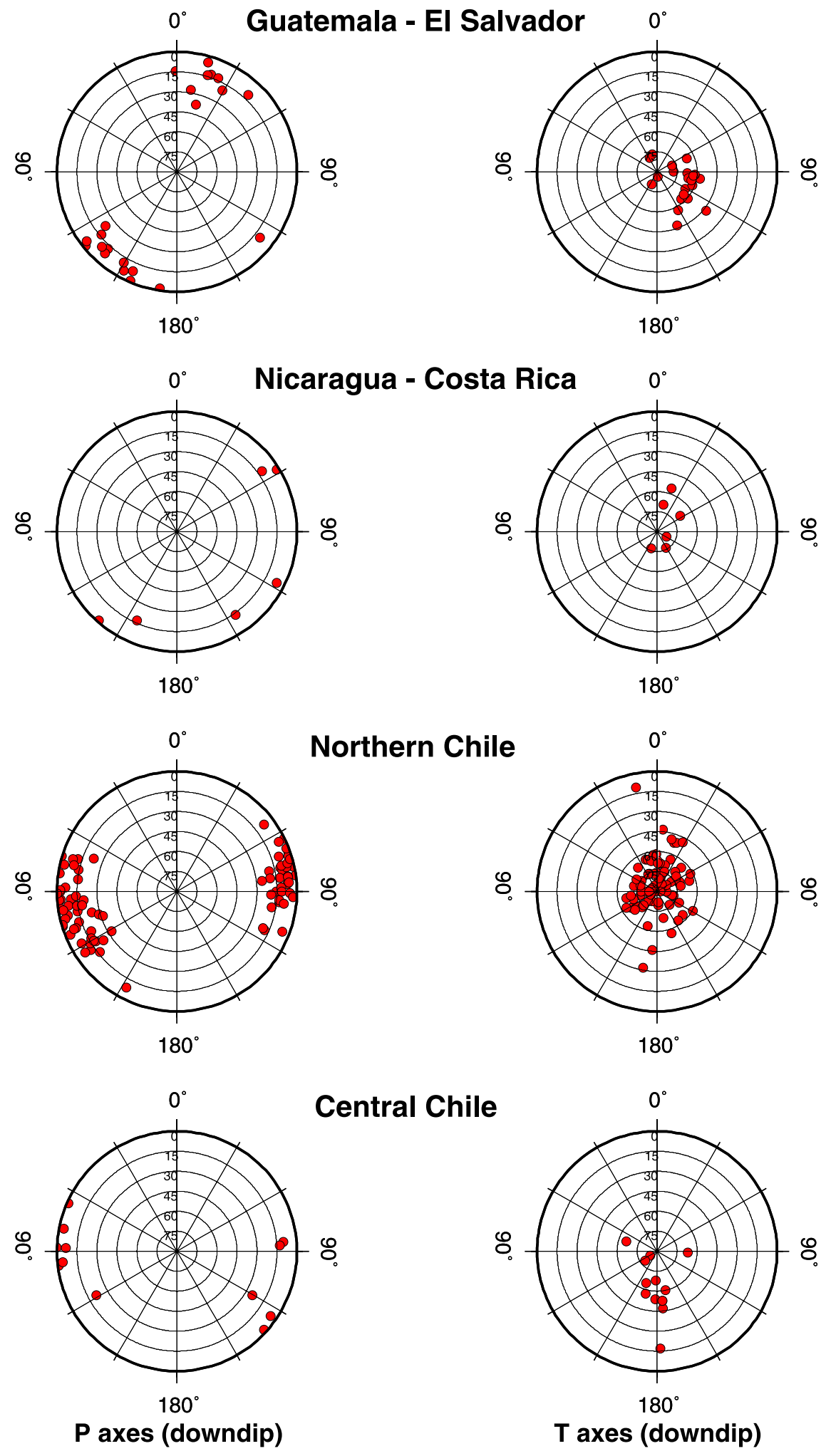

Figure 2. $\mathrm{P}$ (left) and $\mathrm{T}$ (right) axes of intermediate-depth earthquakes from the Harvard CMT catalog projected in the slab reference frame for each of the study areas shown in Figure 1. The slab downdip direction plots at the center of each diagram. The dominant direction of $\mathrm{T}$ axes is less than $30^{\circ}$ of the slab downdip direction. Thus the four studied slabs are dominated by downdip tensional stresses. 


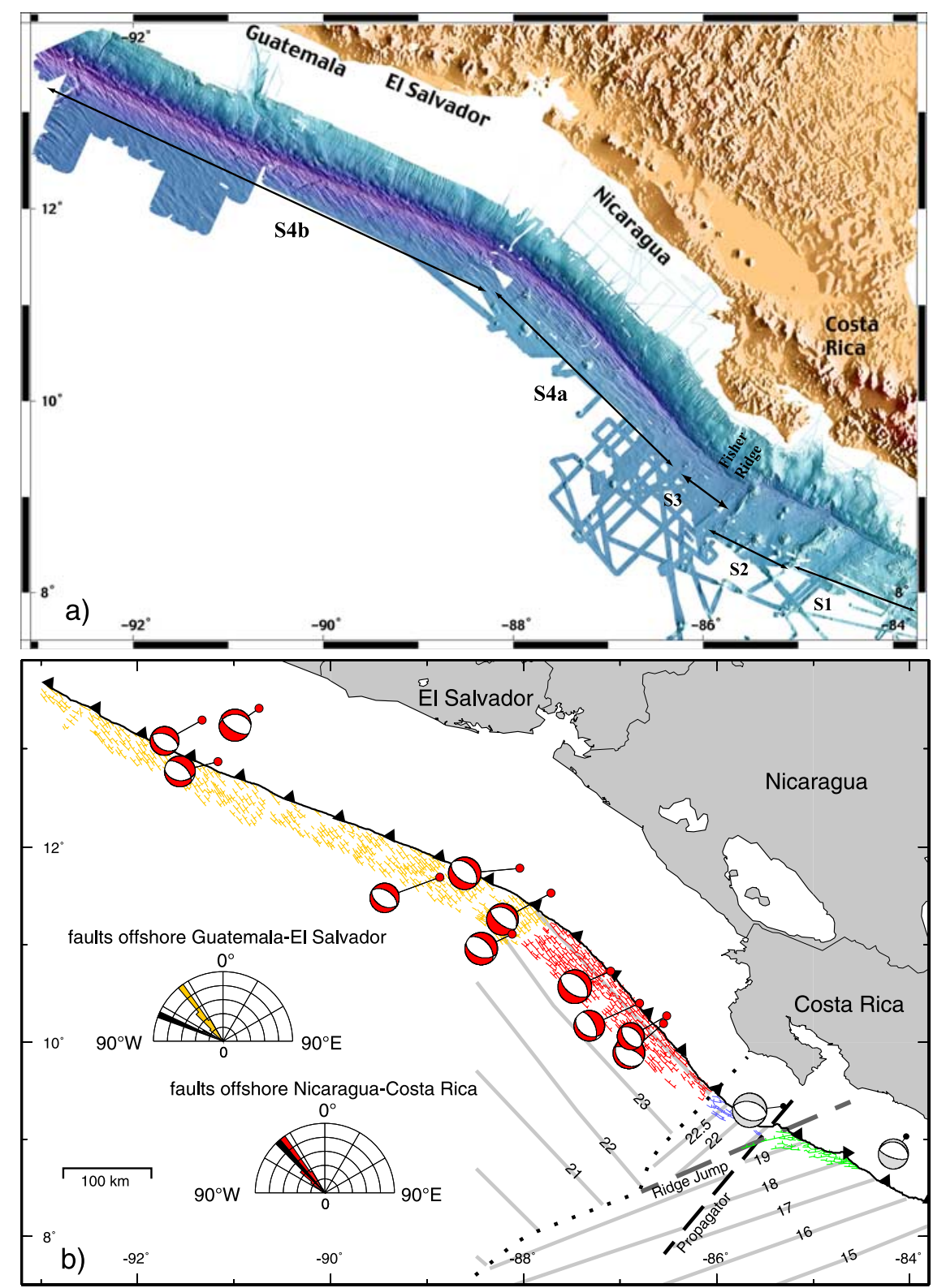

Figure 3. Structure of the Cocos Plate. (a) Color-coded shaded relief bathymetry. The oceanic plate has four segments, labeled S1 to S4, with different morphology and style of faulting. (b) Tectonic structure of the oceanic plate. Segment 1 formed by Cocos Ridge does not display bend-faulting. Faults in segments 2-4 are displayed in green (S2), blue (S3), red (S4a), and orange (S4b). Subsegments S4a and S4b display the same dominant fault strike, but faulting forms different angles with the trench axis. Rose diagrams show fault strike (red and orange) and trench strike (black) for S4a and S4b. Magnetic lineations with age in m.y. after Barckhausen et al. [2001]. Beach balls of fault plane solutions for bending earthquakes are plotted on the centroid location of Harvard CMT catalog, and redfilled circles indicate relocations of Engdahl et al. [1998]. Gray beach balls have not been used in Figure 5.

\subsection{Slab Morphology and Intraslab Seismicity}

[12] Intraslab earthquake abundance and slab morphology change along the subduction zone. Along Middle America there is a spatial correspondence between the abundance of intermediate-depth seismicity and the intensity of faulting in the incoming plate. Higher seismicity is coincident with the area of pervasive bend-faulting (Figure 4), and seismicity decreases sharply east of $\sim 85.5^{\circ} \mathrm{W}$, where faulting intensity also decreases.

[13] The slab dip changes abruptly in central Costa Rica (Figure 4) [Protti et al., 1995; Husen et al., 2003]. A tear of the slab is noticeable at $\sim 60 \mathrm{~km}$ 


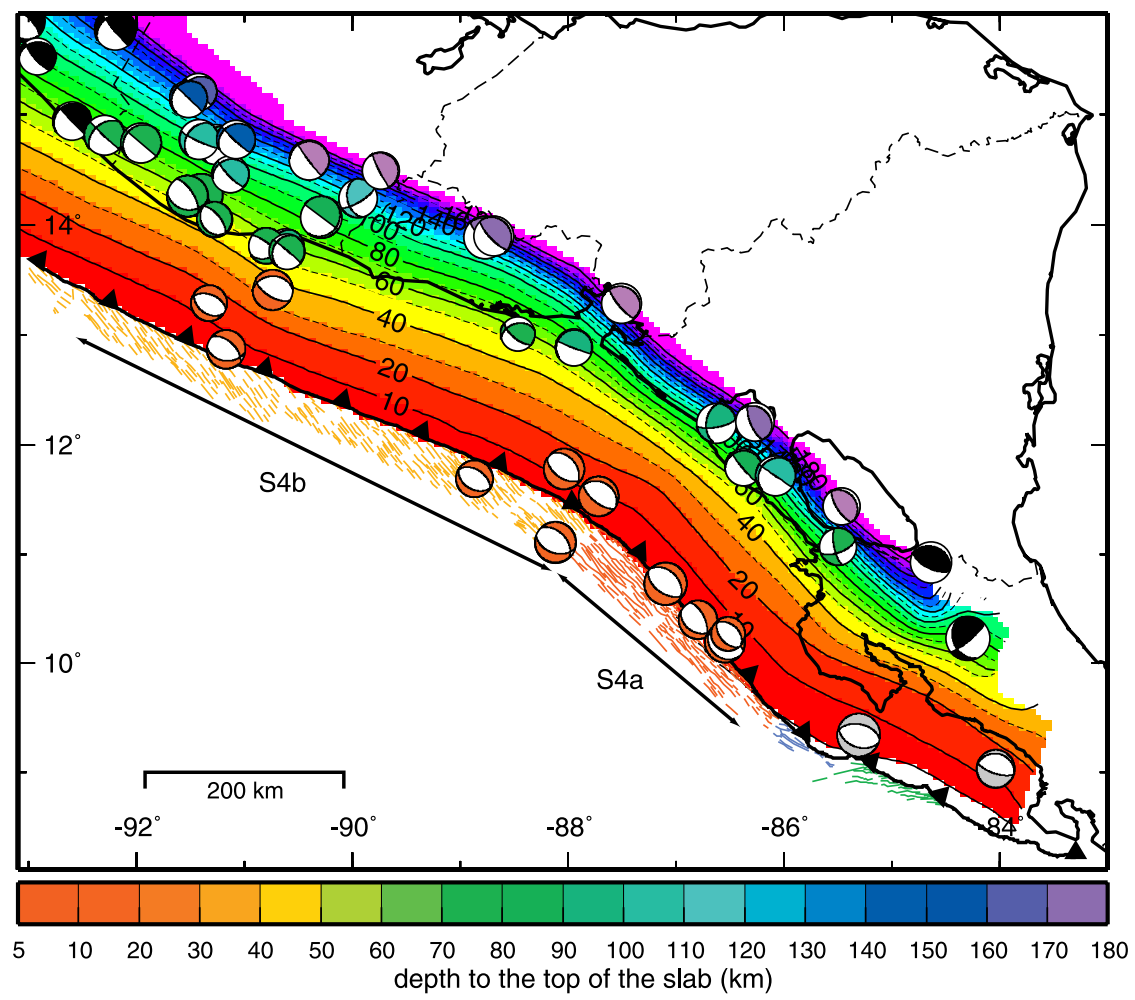

Figure 4. Depth to top of the slab, bending-related earthquakes (red fault plane solutions), and intermediatedepth seismicity (green to lilac fault plane solutions) along Middle America. Pale gray (shallow) and dark gray (deep) fault plane solutions have not been used in Figure 5 because they are not opposite segments S4a and S4b. Trench axis is indicated by line with filled triangles. Bend-faults on oceanic plate are color coded by segments as in Figure 3.

depth and is more abrupt with increasing depth along the slab. In the area where Cocos Ridge subducts, intermediate-depth seismicity is scarce, the slab is poorly defined [Protti et al., 1995; Husen et al., 2003], and no intraslab event appears in the Harvard CMT catalog. Thus we have not extended the slab geometry into this region.

\subsection{Near-Trench Intraplate Seismicity and Intermediate-Depth Seismicity in Middle America}

[14] We focus our analysis on segment 4 (S4a and $\mathrm{S} 4 \mathrm{~b}$ ) where bend-faults maintain a fairly constant azimuth of $\mathrm{N} 40^{\circ} \mathrm{W}$ whereas the slab changes strike by $\sim 25^{\circ}$ (Figures 3 and 4 ). The poles of the nodal planes of near-trench events with dominant normal fault mechanism from Middle America are shown in Figure 5b. A lower hemisphere polar projection is used in all such plots in this paper. Although most earthquakes occur beneath the overriding plate, their depths are consistent with an intraslab location and their focal mechanisms consistent with bending stresses. The poles of four large faults at the Nicaragua trench, imaged in two seismic reflection profiles and multibeam bathymetry [Ranero et al., 2003a], are shown as green-filled circles on Figure $5 \mathrm{~b}$ for comparison with neartrench earthquakes. In addition, the average strike of the populations of bend-faults measured in the bathymetry for segments $\mathrm{S} 4 \mathrm{a}$ and $\mathrm{S} 4 \mathrm{~b}$ is also projected (arrows in Figure 5b). The poles of the two nodal planes cluster in two groups, one of which coincides with the poles of the faults imaged in the seismic data, indicating that these nodal planes are the actual fault planes. The other set of poles corresponds to the slip direction. Pole dip of bend-faults imaged on seismic data cluster at $\sim 45^{\circ}$, while the pole dip of nodal planes of earthquakes cluster at $\sim 46^{\circ} \pm 4$ (Table 1). The azimuths of most poles of auxiliary planes and fault planes are similar to the azimuths of normals to the average fault strike of segments S4a and S4b (symmetrical arrows in Figure 5b).

[15] We have analyzed intraslab events with focal depths between 70 and $200 \mathrm{~km}$ along the two segments (Figure 4). At about $70 \mathrm{~km}$ depth the 

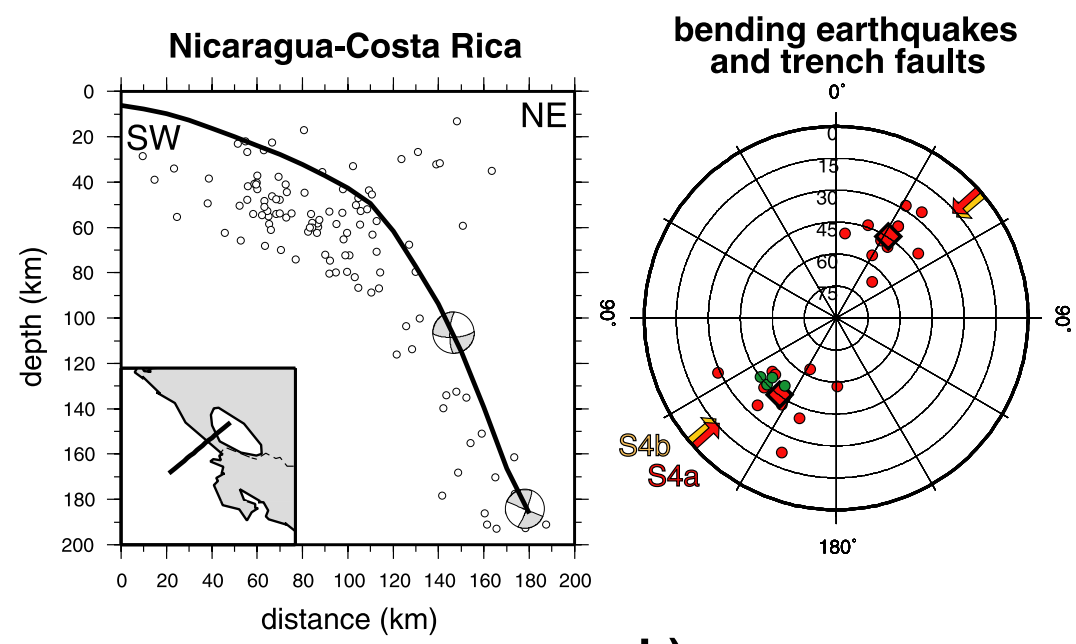

a)

b)
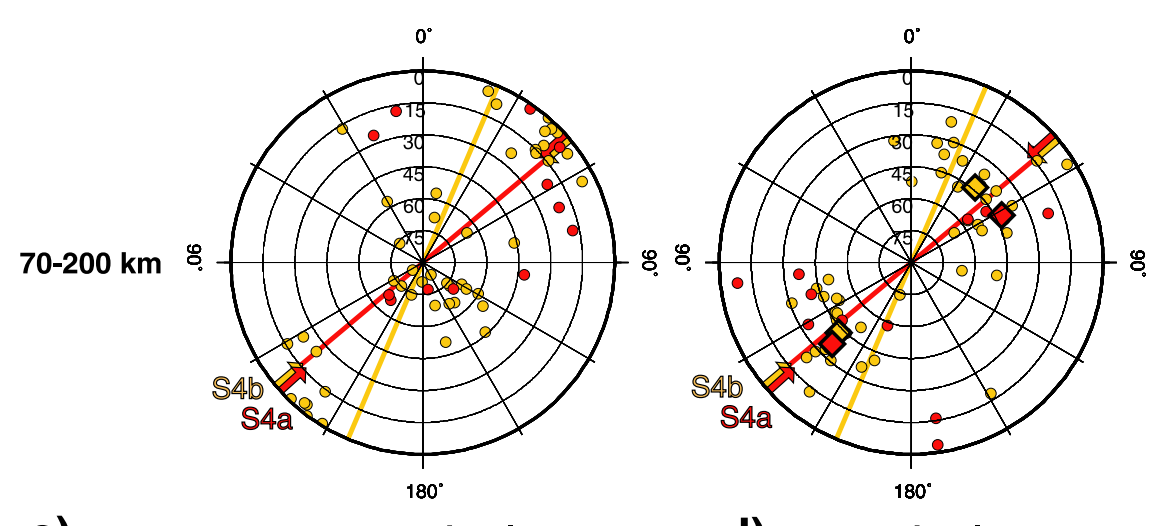

c)

unrotated poles

d) rotated poles

Figure 5. Bending events and intraslab seismicity in Middle America. (a) Cross section showing the top of the slab, and projected seismicity [Engdahl et al., 1998] and sample fault plane solutions from Harvard CMT catalog located $<50 \mathrm{~km}$ from the cross section. (b) Poles of nodal planes of near-trench bending earthquakes. Faults measured on seismic reflection images are green-filled circles. Red large diamonds are the average orientation of NE and SW pole populations. (c) Poles of nodal planes of intermediate-depth events. (d) Poles of nodal planes of intermediate-depth events after rotation for local slab dip. Filled circles are poles of nodal planes for segment S4a (red) and S4b (orange). Large diamonds are the average orientation of NE and SW pole populations for segment S4a (red) and S4b (orange). Red and orange lines across plots are the direction normal to the trench for segments S4a and S4b, respectively. Red and orange arrows are the directions normal to the bend-fault populations of segments S4a and S4b in Figure 3, respectively.

plate has unbent to dive into the mantle with roughly constant dip of $\sim 65^{\circ}$ along segment S4a and $\sim 35^{\circ}$ along segment S4b; thus below that depth coupling with the overriding plate should be minimal and stresses are dominated by slab pull forces (Figure 5a). Poles of intraslab earthquakes from the Nicaragua segment S4a (red-filled circles) and from the El Salvador-Guatemala segment S4b (orange-filled circles) appear poorly grouped before rotations that correct for slab dip (Figure 5c), but rotated poles group better in two populations (Figure 5d). To show the angular relationship of the nodal planes of intermediate-depth earthquakes with the trench strike and trench-fault strike, the normal to the trench strike and to the average trench-fault azimuth for segments $\mathrm{S} 4 \mathrm{a}$ and $\mathrm{S} 4 \mathrm{~b}$ is shown at the stereograms by solid lines and arrows, respectively. The two groups of poles roughly map at about the normal to the trench along segment S4a (red line in Figure 5d), i.e., that correspond to rupture planes roughly parallel to the trench faults (colored arrows in Figure 5d). This correspondence occurs for the nodal planes of earthquakes in both segments S4a and S4b. The average orientation of 

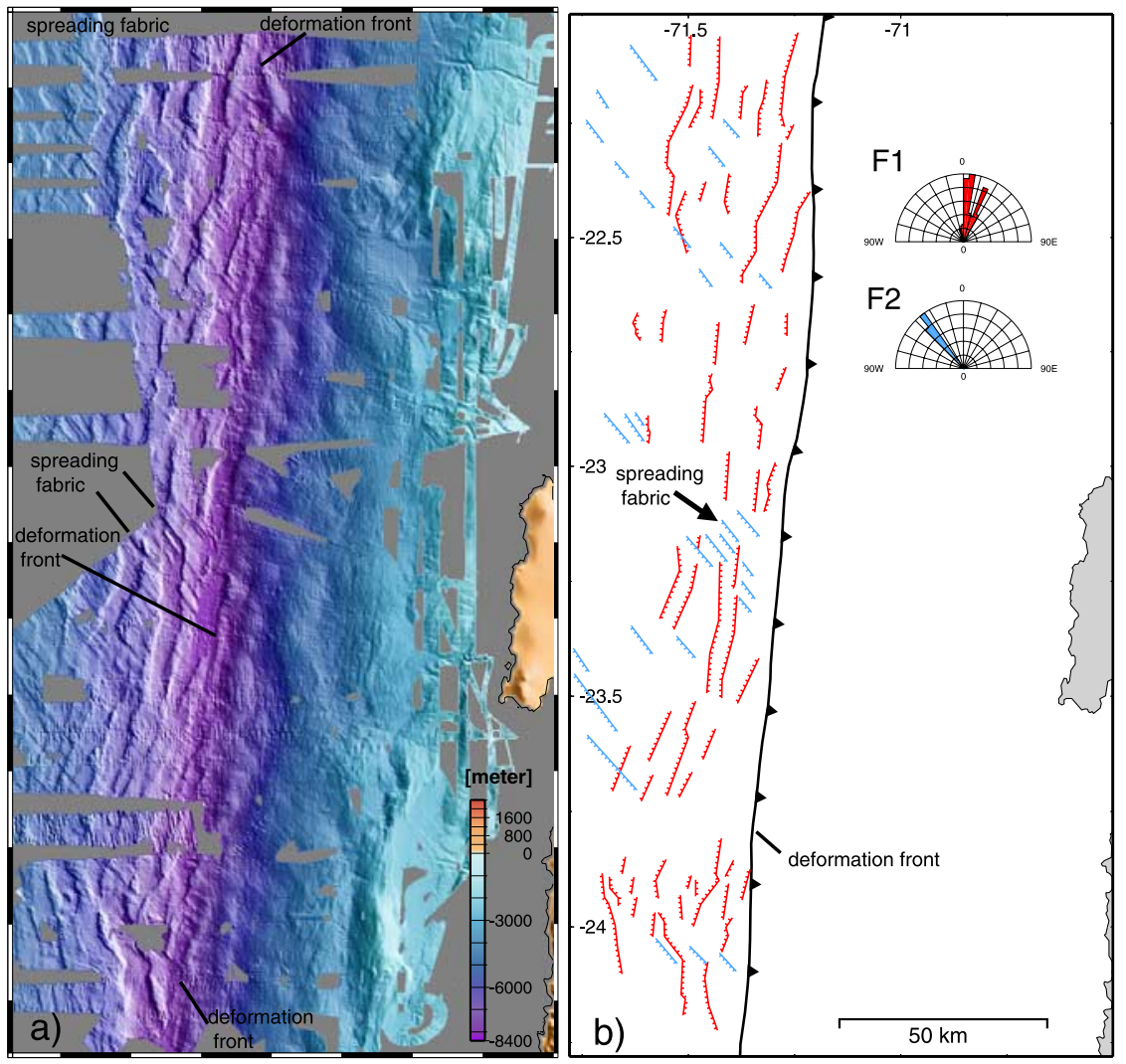

Figure 6. Structure of the oceanic plate along the north Chile subduction zone. (a) Shaded relief, color-coded multibeam bathymetry along north Chile subduction zone. The oceanic plate shows intense bending-related faulting with increasing offsets approaching the trench axis. (b) Interpretation of bend-faults in the bathymetry. Two fault trends develop during bending, one trench parallel (F1) and one strongly trench oblique reactivating the seafloor spreading fabric (F2). Rose diagrams show dominant orientation of bend-faults and are color coded to faults in the oceanic plate.

each sets of poles in the SW quadrant (large diamonds) maps near the strike of the trench of segment $\mathrm{S} 4 \mathrm{a}$ and trench faults.

\section{Chile}

[16] Along the Chile subduction zone the Nazca plate subducts beneath the South American plate at $\sim 9 \mathrm{~cm} / \mathrm{yr}$ with a roughly trench normal convergence vector. We have studied the structure of the incoming oceanic plate of northern and central Chile (Figure 1) and mapped the top of the slab along $16^{\circ}$ of latitude $\left(20^{\circ} \mathrm{S}-36^{\circ} \mathrm{S}\right)$ of this subduction zone. Shallow near-trench seismicity is absent along most of this segment of the trench, but abundant intermediate-depth seismicity can be usefully compared to incoming-plate fault patterns.

\subsection{North Chile Incoming Plate Structure}

[17] In north Chile the incoming plate has been mapped for $\sim 250 \mathrm{~km}$ along the trench. The in- coming plate is $\sim 48 \mathrm{Ma}$ and has a $\sim 7 \mathrm{~km}$ thick crust [Ranero and Sallares, 2004]. Plate bending is partially accommodated by pervasive trenchsubparallel faulting and, less prominent, faulting at $\sim 40^{\circ}$ to the trench strike, parallel to the magnetic lineations (Figure 6). The trench-subparallel fabric commonly forms half grabens tilted toward the trench, but also sometimes forms full grabens (Figure 6b). Faulting parallel to the magnetic lineations forms half grabens (Figure 6b).

\subsection{Central Chile Incoming Plate Structure}

[18] In central Chile the incoming plate has been partially mapped along a $\sim 600 \mathrm{~km}$ long segment (Figure 7). Bathymetric data extend across the trench slope and outer rise to the undeformed oceanic plate. The oceanic plate is covered by $\sim 100 \mathrm{~m}$ of pelagic sediment and the morphology of the underlying igneous crust is clearly displayed in the bathymetric map. Away from the areas 

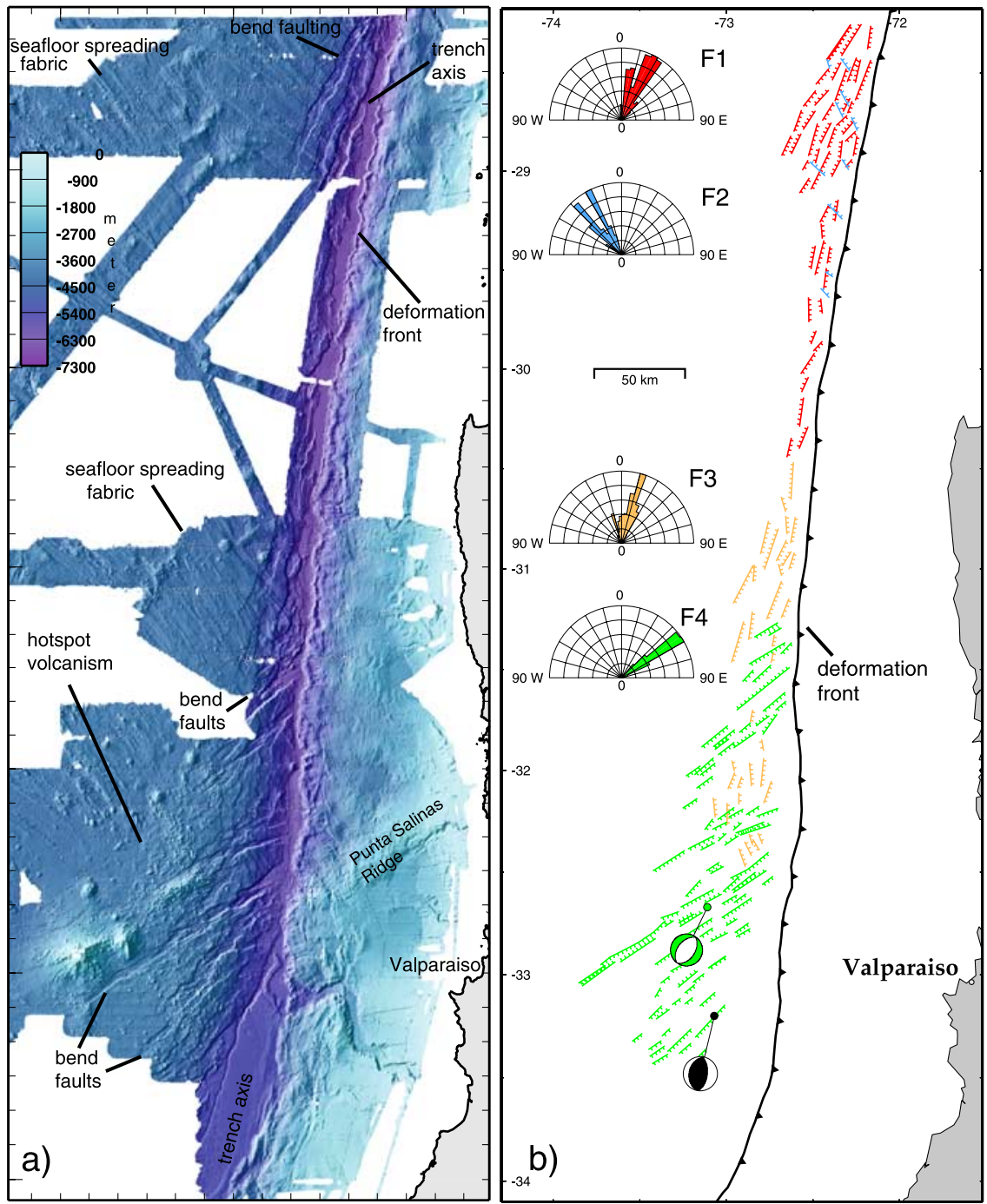

Figure 7. Structure of the oceanic plate along the central Chile subduction zone. (a) Shaded relief, color-coded multibeam bathymetry. In the north, away from the trench a NW-SE seafloor spreading fabric dominates the morphology. In the south the spreading fabric has been obliterated by the volcanism of the Juan Fernández Ridge. Near the trench, bend-faulting is pervasive. (b) Interpretation of bend-faults. Four trends develop during plate bending. In the north, faults F1 are subparallel to the trench and faulting F2 reactivates the spreading fabric. Near Juan Fernández Ridge the strike of bend-faults F3 is parallel to the trench and F4 is strongly oblique to the trench and parallel to the volcanic chain. Rose diagrams show dominant orientation of bend-faults and are color-coded to faults in the oceanic plate. Fault plane solutions for two intraplate bending events are also shown. The green-filled fault plane solution is a normal fault earthquake with planes subparallel to bend-faults F4. The black-filled fault plane solution is a deeper thrust event with planes parallel to the trench.

deformed by bend-faulting the plate shows two distinct regions with different seafloor morphologies. A series of low-relief ridges striking NW and WNW are the expression of the fabric formed at the spreading center. The spreading center fabric is particularly clear in the northern region of the map but can also be observed toward the south to about $32^{\circ} \mathrm{S}-32.5^{\circ} \mathrm{S}$ where it gives way to an area with numerous volcanoes. The volcanoes are part of the
Juan Fernández Ridge, a hot spot track, and extend in a swath oblique to the trench between $\sim 31.5^{\circ} \mathrm{S}-$ $33.5^{\circ} \mathrm{S}$. Volcano width ranges typically from $\sim 10 \mathrm{~km}$ to hundreds of meters, but two larger volcanic edifices and a ridge occur at the crestal area of the swell striking NE from $33^{\circ} \mathrm{S}$ to $32.5^{\circ} \mathrm{S}$. The swell and volcanoes were formed about $8.5 \mathrm{Ma}$ and sit over 38-39 Ma lithosphere [von Huene et al., 1997; Yáñez et al., 2001]. 
[19] Bending-related deformation changes notably along the area. In the northern region, not influenced by hot spot magmatism, dominant bendfaulting forms grabens subparallel to the trench axis and at large angles to the seafloor-spreading fabric (F1 in Figure 7). Here, the seafloor-spreading fabric starts to be reactivated near the trench axis (F2 in Figure 7). Approaching the Juan Fernández Ridge, bend-fault strike and faulting intensity change. Trench-subparallel faulting decreases in intensity (F3 in Figure 7) and a dominant set of faults roughly normal to the seafloor spreading fabric and at large angles to the trench axis forms at about $31.5^{\circ} \mathrm{S}$ ( F4 in Figure 7). The F4 faulting is roughly parallel to Juan Fernández Ridge and extends much farther across the trench slope than the other bend-faulting fabrics. Faults just to the south of the large volcanoes develop $\sim 100 \mathrm{~km}$ away from the trench axis and gradually increase in offset to form $\sim 1 \mathrm{~km}$ high scarps at the trench where they become buried under trench sediment infill (Figure 7a). A large normal fault earthquake (Mw 6.7) south of Juan Fernández Ridge ruptured along a plane roughly parallel to the trench faults (Figure 7b).

\subsection{Slab Morphology and Intraslab Seismicity}

[20] The map of the depth to the top of the slab (Figure 8) obtained using global travel time tomography [Villaseñor et al., 2003] and seismicity [Engdahl et al., 1998] is similar to previous maps [Cahill and Isacks, 1992; Kirby et al., 1996]. The slab progressively shallows from the north toward the area of subduction of Juan Fernández Ridge where it flattens between $\sim 75-125 \mathrm{~km}$ depths. The area of the flat slab is not restricted to the locus of subduction of Juan Fernández Ridge but extends farther north for $\sim 200 \mathrm{~km}$ to latitude $\sim 28^{\circ} \mathrm{S}$. South of the flat slab the plate steepens abruptly to dips larger than those north of the flat-slab region.

[21] The distribution and maximum depth of intraslab seismicity changes along the subduction zone in concert with variations in slab morphology (Figure 8). In the north, steep subduction is associated with abundant intermediate-depth seismicity. Intermediate-depth seismicity decreases notably between $25^{\circ}-28^{\circ} \mathrm{S}$ approaching the flat slab area. In the flat slab area intermediate-depth earthquakes occur in clusters. One of the clusters centered at $\sim 31^{\circ} \mathrm{S}$ aligns with Juan Fernández Ridge offshore [Kirby et al., 1996] and occurs at about the projection of the subducted segment of the ridge

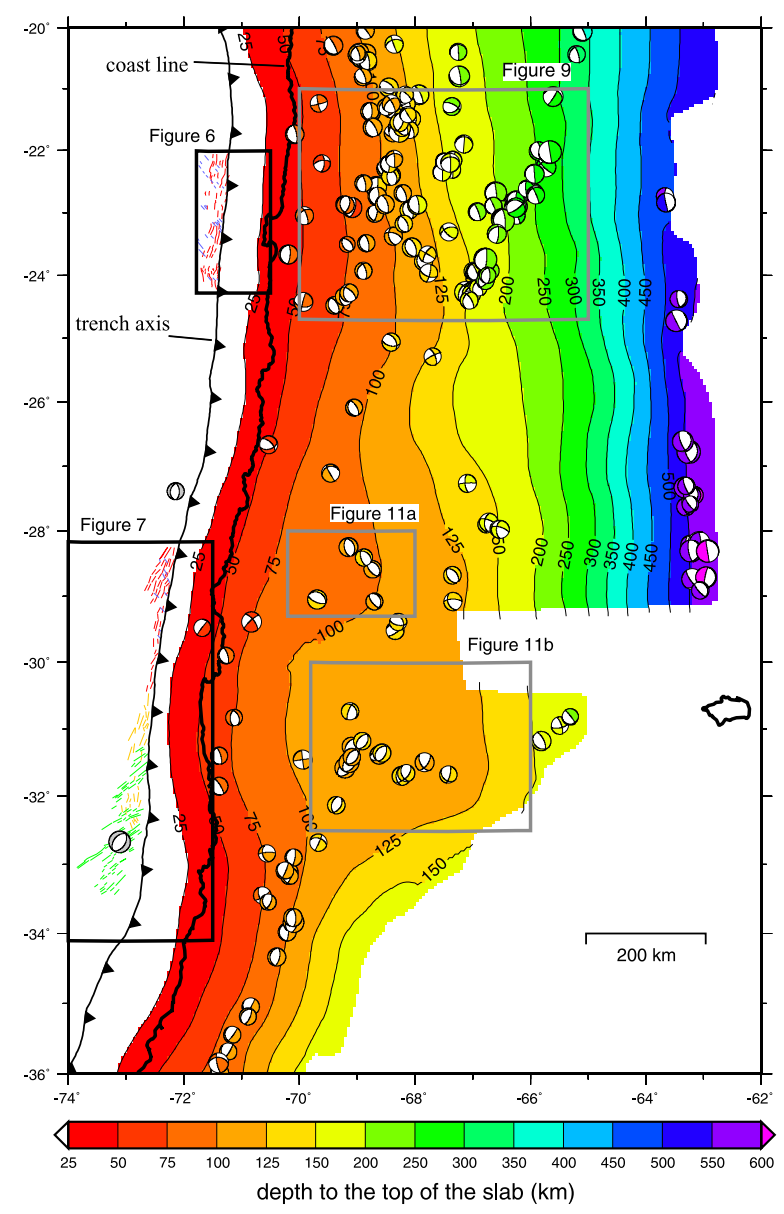

Figure 8. Depth to the top of the slab and seismicity (fault plane solutions color-coded to focal depth) beneath central Chile. Gray boxes mark areas with intraslab seismicity analyzed in Figures 9 to 11 . Coastline is heavy irregular line; trench axis is indicated by line with filled triangles. Black boxes mark areas with bathymetry shown in Figures 6 and 7. Gray fault plane solutions at the trench are bending events with normal fault mechanisms.

[Yánez et al., 2001]. South of the flat slab, where the plate becomes steeper, intermediate-depth seismicity is again homogeneously distributed although limited to a narrower depth range than in the northernmost area. Deep earthquakes $(>350 \mathrm{~km})$ appear restricted to the northern area where the plate has been mapped continuously with tomographic images down to $\sim 600 \mathrm{~km}$ depth.

\subsection{Bending-Related Faulting and Intermediate-Depth Seismicity in North Chile}

[22] No near-trench bending earthquakes exist in the Harvard CMT catalog for northern Chile, thus 
a)
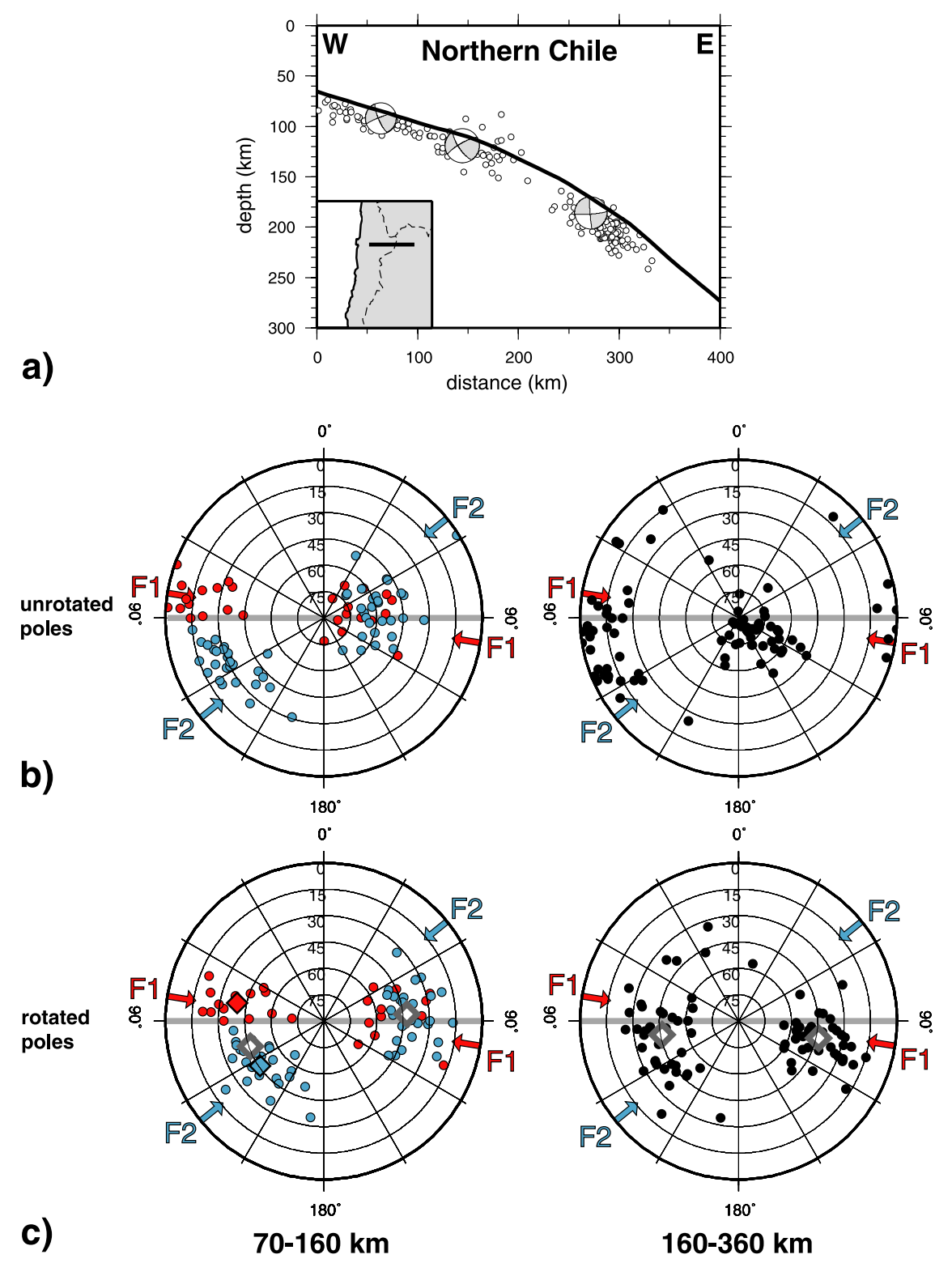

Figure 9. Intermediate-depth seismicity in north Chile. Location of seismicity is in Figure 8. (a) Cross section showing the top of the slab, and projected seismicity [Engdahl et al., 1998] and sample fault plane solutions from Harvard CMT catalog located $<50 \mathrm{~km}$ from the cross section. (b) Poles of nodal planes of intermediate-depth events for two depth ranges. (c) Poles of nodal planes of intermediate-depth events after rotation for local slab dip. In the depth range 70-160 km (left column), red- and blue-filled circles are pole populations determined from the density diagrams shown in Figure 10. Large red and blue diamonds are the average orientation of the red and blue pole populations in the $\mathrm{W}$ hemisphere. Large gray diamonds are average orientation of all poles in the $\mathrm{W}$ and $\mathrm{E}$ hemisphere. Gray line across plots is the direction normal to the trench. F1 and F2 are the directions normal to the strike of bend-fault populations in Figure 6.

we can only compare intraslab seismicity to bendfault patterns in the incoming plate. In northern Chile the continental crust is $50-60 \mathrm{~km}$ thick [Yuan et al., 2000], thus we examine intermediate-depth seismicity below $70 \mathrm{~km}$ where the slab appears to be decoupled from the overriding plate. The analysis has been done for events from $21^{\circ}-$ $25^{\circ} \mathrm{S}$ between 70 to $160 \mathrm{~km}$ and 160 to $360 \mathrm{~km}$ (Figure 8) corresponding to two areas of the slab with different dip that are separated by a small gap in seismic activity (Figure 9a). Poles of nodal planes (not rotated to account for slab dip) give two groups with asymmetric dips (Figure 9b). After correction for slab dip, the poles from both 

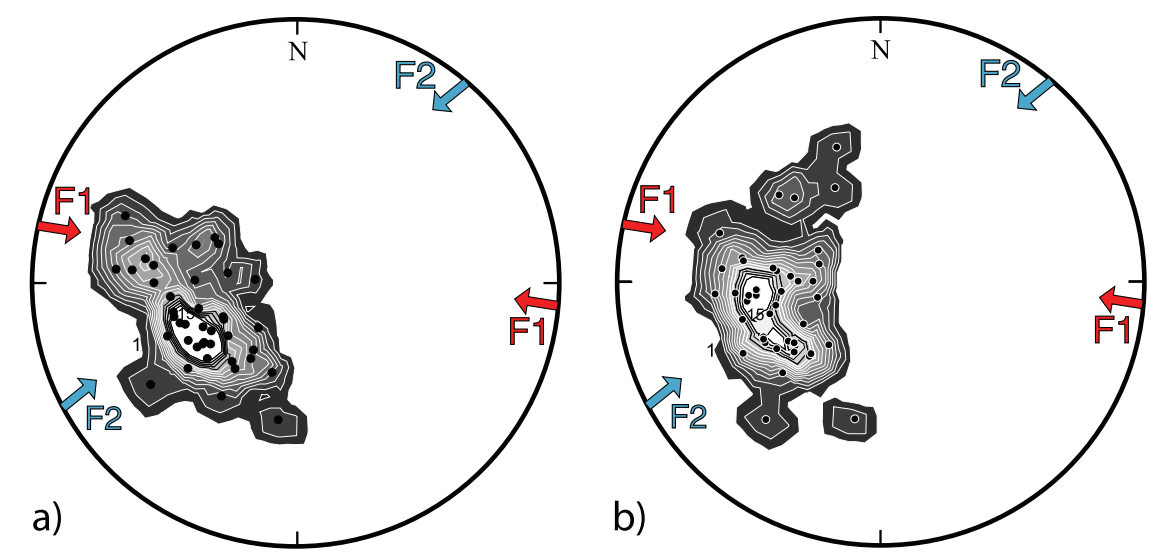

Figure 10. Density diagrams of rotated poles of the nodal planes of north Chile intermediate-depth earthquakes. The density diagram is shown in an equal angle lower hemisphere projection. (a) Poles of nodal planes from 70$160 \mathrm{~km}$ depth in the $\mathrm{W}$ hemisphere shown in Figure 9c. The diagram shows that the poles arrange in two well-defined clusters with average strikes similar to trench faults systems F1 and F2. (b) Poles of nodal planes from 160-360 km depth in the $\mathrm{W}$ hemisphere shown in Figure 9c. The maximum of the distribution has an elongated shape that overlaps with the F2 strike.

depth ranges map into two groups with roughly symmetric dips (Figure 9c). Although the groups display some spread, average pole dips range between $46^{\circ} \pm 6$ in the $\mathrm{W}$ hemisphere and $-43^{\circ} \pm 5$ in the E hemisphere (Table 2), similar to the results from Middle America. Pole azimuths are tighter in the eastern hemisphere. In the western hemisphere they spread over a range similar to the azimuths of the two bend-fault populations of the incoming plate (Figure 9c, azimuths F1, F2). The pole density distribution of the $70-160 \mathrm{~km}$ deep seismicity suggests that the earthquakes arrange in two distinct groups (Figure 10a) and that the average strike of the nodal planes of each of the groups (Group 1 and 2 in Table 2) is very similar to the average strike of bend-faults F1 and F2, respectively (Table 2 and Figure 10a). The pole density distribution of the $160-360 \mathrm{~km}$ deep
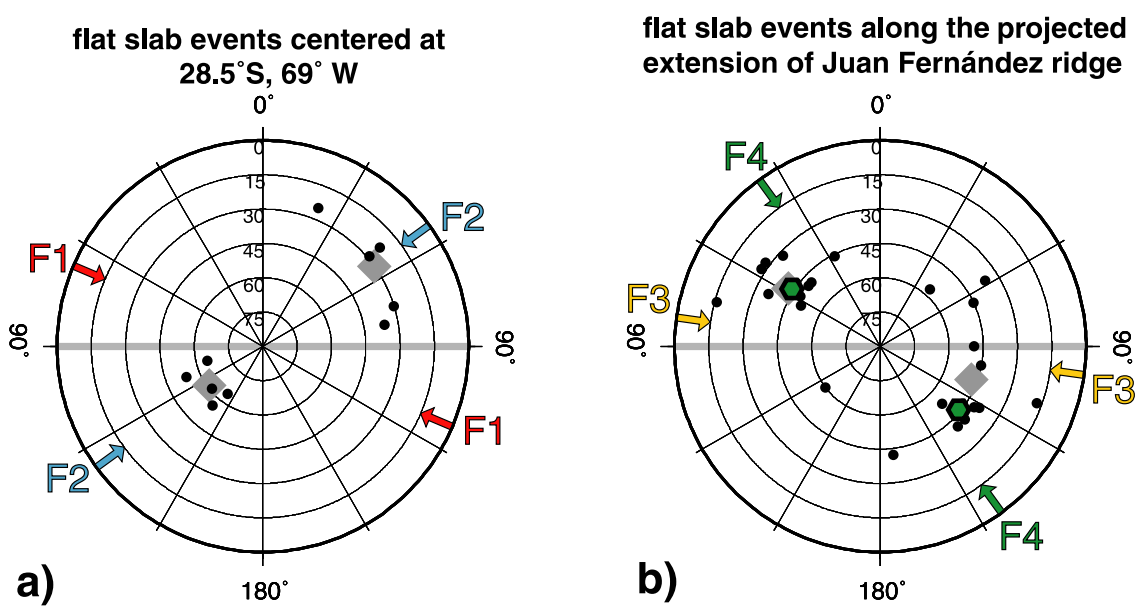

Figure 11. Intermediate-depth seismicity in central Chile of two clusters in the flat slab area. (a) Poles of nodal planes of intermediate-depth events in the northern area of the flat slab $\left(28.5^{\circ} \mathrm{S}, 69^{\circ} \mathrm{W}\right)$. Large gray diamonds are average orientation of the SW and NE pole populations. F2 marks the normal to the strike of the bend-faulting reactivating the seafloor spreading fabric and F1 of the trench-subparallel faults (see Figure 7). (b) Poles of nodal planes of intermediate-depth events along the projected extension of the Juan Fernández Ridge. F4 is normal to the strike of bend-faulting parallel to Juan Fernández Ridge and F3 subparallel to the trench (see Figure 7). Large gray diamonds are average orientation of the NW and SE pole populations. The green-filled hexagons are the poles of a normal fault event at the trench. Location of clusters is shown in Figure 8. 
seismicity does not show clear clustering in two groups, but the maxima are closer to the F2 fault fabric (Figure 10b).

\subsection{Bending-Related Faulting and Intermediate-Depth Seismicity in Central Chile}

[23] Two clusters of intermediate-depth events analyzed from the flat slab area show different patterns than those beneath northern Chile. In the flat slab area the dip of the plate is negligible, therefore no rotation is necessary to compare outerrise faulting and seismicity. A small cluster centered at $\sim 28.5^{\circ} \mathrm{S}$ in the northern region of the flat slab (Figure 8) is the only group that has strongly asymmetric pole dips, corresponding to nodal planes dipping $30^{\circ} \pm 20$ and $60^{\circ} \pm 9$ with respect to the top of the slab (Figure 11a and Table 3). The azimuths of the intraslab nodal planes are consistent with the orientation of the F2 fabric, strongly oblique to the trench and slab strikes. A second cluster at $\sim 31.5^{\circ} \mathrm{S}$ occurs near the southern end of the flat slab (Figure 8). This elongated cluster is roughly coincident with the projected continuation of the Juan Fernández Ridge [Yáñez et al., 2001]. Events from this cluster give two moderately symmetric groups of poles dipping $42^{\circ} \pm 14$ and $48^{\circ} \pm 10$ (Figure 11b). The pole azimuths are different to the other events analyzed in Chile, however, the group in the NW quadrant is similar to the strike of the F4 faults parallel to the Juan Fernández Ridge, and in particular to the strike of the nodal planes of a trench Mw 6.7 normal-fault earthquake (Figure 11b). Thus the nodal planes of both analyzed clusters have azimuths similar to those of trench faults that strike at high angle to the strikes of the trench and slab.

\section{Discussion}

\subsection{Controls on Style of Bend-Faulting}

[24] The bathymetric maps of Middle America and Chile show that subduction-linked plate bending creates a complex tectonic pattern that varies along subduction zones. The bend-faulting pattern seems to be governed by the interaction of local structures in the incoming plate with trench-perpendicular plate-bending stresses. The strike of bend-faults, the width of the region of faulting, the reactivation of the seafloor-spreading fabric and/or the formation of new faults, the formation of half or full grabens, and the predominant fault-dip direction seem to systematically correlate with changes in the angle between the seafloor-spreading fabric and the axis of bending, and local changes in thickness of the oceanic crust.

[25] When the seafloor-spreading fabric is at $<\sim 30^{\circ}$ angles to the trench, the fabric is reactivated during bending and no significant new set of faults develops (e.g., segment S4a and S4b in Figure 3). Similar observations have been documented at several other subduction zones [Masson, 1991]. At fast spreading centers with opening rates comparable to those at which the oceanic crust off Middle America was created, inward and outward faults form in similar proportions [Carbotte and Macdonald, 1994]. However, during bending near the trench one set is predominantly reactivated so that faulting dips dominantly in one direction forming half grabens, full grabens being relatively rare. When the inherited fabric subducts at angles larger than $\sim 40^{\circ}$ two distinct sets of faults may form [Masson, 1991]. The inherited fabric breaks consistently in one direction forming half grabens, while the new fabric may form half or full grabens (Figures 6 and 7). If the seafloor-spreading fabric is nearly perpendicular to the trench axis, only new faults form, creating dominantly full grabens in a more restricted area of faulting compared to areas where inherited faults are reactivated (e.g., segment 3 in Figure 3).

[26] Faulting associated with subduction of aseismic ridges is also variable. The thick-crust Cocos Ridge bends little, and no bend-faulting occurs in its vicinity (Figure 3 ). In contrast, the flanks of the smaller Juan Fernández Ridge are associated with pervasive ridge-parallel bend-faulting at high angles to the trench (Figure 7). Apparently, the broad area $(>250 \mathrm{~km}$, Figure 1) of up to $20 \mathrm{~km}$ thick crust of Cocos Ridge inhibits bend-faulting. However, the Carnegie ridge with similar structure shows a $\sim 20 \mathrm{~km}$ wide area of bend-faulting [Collot et al., 2004]. This different bending behavior may be induced by the thicker overriding plate of South America. The narrower area of anomalous crust of Juan Fernández Ridge (Figure 1) induces concentrated ridge-parallel faulting along the trench, leading to widespread trench-normal faulting over a $\sim 200 \mathrm{~km}$ wide area parallel to the seamount chain. We speculate that this may occur because the emplacement of the off-axis volcanic loads of the Juan Fernández Ridge created ridge-parallel lithospheric weaknesses that are reactivated during bend-faulting. Although the specific mechanism is still unknown, it is clear that the emplacement of volcanic islands can preferentially weaken oce- 
anic lithosphere within the region of compensating plate flexure. For example, the shallow magmatic feeders of the northern Hawaiian Arch volcanic fields are elongated parallel to the strike of the Hawaiian Island Chain [Clague et al., 1990]. Similar preexisting structures parallel to Juan Fernández Ridge may be reactivated during bending. In contrast, the large volcanic edifices of Juan Fernández Ridge are not faulted as they enter the trench.

\subsection{Comparison of Near-Trench Earthquakes, Bend-Faults, and Intraslab Seismicity}

[27] Previous attempts to test the hypothesis of fault reactivation by intermediate-depth seismicity have relied on the analysis of only earthquake focal mechanisms [Jiao et al., 2000; Christova and Scholz, 2003; Chen et al., 2004; Brudzinski and Chen, 2005]. Jiao et al. [2000] report that the clusters of the two nodal planes of near-trench earthquakes in Tonga and Kurile show an asymmetric dip distribution and that the inferred fault plane dips $\sim 60^{\circ}$. They also show that intermediatedepth earthquakes have a similar dip asymmetry and azimuth distribution, supporting the hypothesis that seismicity occurs at preexisting fault planes. In contrast, in our study areas we observe that nodal planes of near-trench earthquakes and faults imaged in seismic data dip symmetrically $\sim 45^{\circ}$ and that the dip of most intermediate-depth events ranges between $\sim 40^{\circ}-50^{\circ}$ with no obvious asymmetric distribution. However, the similar dip of trench faults and intermediate-depth seismicity alone, although necessary, is not conclusive evidence for fault reactivation in our study areas because a $45^{\circ}$ angle is expected for the formation of (new) faults in an isotropic media under a typical stress distribution in the slab [e.g., Jiao et al., 2000]. Thus, to test the fault reactivation hypothesis, we compare the strike of the nodal planes of intermediate-depth seismicity and bendfaults at the trench. If intraslab earthquakes were generated by new faults controlled by the regional stresses in the slab, then they should show a distribution of nodal planes roughly parallel to the slab strike for slabs under downdip tension [e.g., Christova and Scholz, 2003] like in Middle America and Chile (Figure 2). Those intraslab seismicity patterns should not necessarily correspond to seismicity or fault patterns at the trench, that seem to be governed by other parameters than just regional stresses as discussed above.

\subsubsection{Middle America}

[28] Along the Middle America Trench the orientation of one set of nodal planes of near-trench intraplate earthquakes is consistent with the average azimuth of faults measured in the bathymetry along segments S4a and S4b (Figure 5b). The group in the SW quadrant maps at the location of the faults imaged on seismic data indicating that those poles correspond to the rupture planes (Figure 5b).

[29] The poles of intermediate-depth seismicity map in two groups, and the average strike of the nodal planes in the southwest quadrant is similar to the strike of bending earthquakes and trench faults imaged on seismic data, and very close to the strike of the trench and slab of segment S4a (Figures 5b and $5 \mathrm{~d}$ and Table 1). Interestingly, the azimuth of the poles of intermediate-depth seismicity of the segment S4b $\left(230^{\circ} \pm 7\right.$, orange poles in Figure $\left.5 \mathrm{~d}\right)$ cluster close to the azimuth of the trench faults $\left(229^{\circ} \pm 9\right.$, red and orange arrows in Figure 5d) but far from the azimuth of the slab at segment S4b $\left(204^{\circ} \pm 3\right.$, orange line in Figure 5d), i.e., away from the slab-parallel azimuth that would be expected for newly formed faults. Thus nodal planes of intermediate-depth seismicity remain in average parallel to the strike of trench faulting across segments $\mathrm{S} 4 \mathrm{a}$ and $\mathrm{S} 4 \mathrm{~b}$ even though the slab strike changes by $\sim 25^{\circ}$. Therefore the data are consistent with the fault reactivation hypothesis for most intraslab earthquakes.

\subsubsection{North Chile}

[30] In north Chile, rotated intermediate-depth focal mechanisms in the depth range of 70-160 km occur in two well-defined groups in the western quadrant that are centered on the average of the two bend-fault populations (F1 and F2 in Figure 9c, Figure 10a, and Table 2). The poles at $160-360 \mathrm{~km}$ depth do not arrange into two groups in the western quadrant (Figure 10b), but group somewhat preferentially with F2 (Figures 9c and 10b and Table 2). Thus the azimuth range of the nodal planes for the $70-160 \mathrm{~km}$ depth group may indicate reactivation of the F1 and F2 bend-faults at the trench. The group at $160-360 \mathrm{~km}$ depth may preferentially reactivate F2 although some poles are close to the F1 azimuth. However, it is also possible that deep in the subduction zone the structure of the slab inherited from bending-related deformation at the trench is somewhat different to the current trench structure. The poles at the eastern quadrant at both depth ranges arrange more tightly and close to the 
downdip direction of the slab, i.e., parallel to the slab pull direction. These poles may indicate that even though faults have different orientations, slip of the faults occurs in the direction favored by the main regional stresses. The F1 azimuth is roughly parallel to the slab strike and thus could also correspond to the strike of newly formed rupture planes. However, the F2 fault system originates from the reactivation of the seafloor-spreading fabric during bending and strikes at $39^{\circ} \pm 3$ to the trench and slab direction, thus it is not simply governed by the regional stress field. Therefore the intraslab seismicity rupturing with planes parallel to F2 provides support to the fault-reactivation hypothesis.

\subsubsection{Central Chile}

[31] The large dimension of the flat slab of central Chile implies that slab pull is greatly diminished, indicating that intermediate-depth seismogenesis here does not require this driving force [Brudzinski and Chen, 2005]. Brudzinski and Chen [2005] analyzed intermediate-depth earthquakes across the entire flat slab area and found no obvious preferred orientation of fault plane solutions. They proposed that intermediate-depth earthquakes here are probably not caused by reactivation of preexisting faults, arguing that the scatter of nodal planes requires an unlikely incoherent network of preexisting faults that implies rapid, lateral variations of tectonic stress along the trench [Brudzinski and Chen, 2005]. However, the bathymetric maps show that exactly this type of variability in trench faulting is present here along the Chile trench (Figures 6 and 7).

[32] We have analyzed two clusters of intermediate-depth earthquakes in the flat slab and compared them to the trench fault structure located updip of each of the intraslab seismicity clusters. A northern cluster located at $\sim 28.5^{\circ} \mathrm{S}$ (Figure 8) is the only case in our study showing clear asymmetry in the dips of nodal planes $\left(\sim 30^{\circ}\right.$ and $\left.\sim 60^{\circ}\right)$. The nodal planes of the cluster strike $234^{\circ} \pm 9$, and consistent with reactivation of the seafloor spreading fabric $\mathrm{F} 2$ at $234^{\circ} \pm 11$ (Figures 7 and 11a). Even though the seafloor spreading fabric does not form a welldeveloped system of faulting at the trench, bending of the oceanic plate continues underneath the continental slope and bend-faults have been proposed to continue growing as the downgoing plate continues to bend beneath the continental margin [von Huene and Ranero, 2003].
[33] The cluster of intermediate-depth seismicity located near the southern end of the flat slab (Figure 8) has been previously attributed to reactivation of structures in the volcanic edifices of the Juan Fernández Ridge [Kirby et al., 1996]. Our analysis supports that at least some of these earthquakes reactivate bend-faults formed at the trench. The poles in the NW quadrant correspond to nodal planes that roughly consistent with the strike of faults parallel to the ridge in the incoming plate (F4 in Figure 11b, Table 3). Support for the hypothesis that at least some of the flat slab events reactivate trench faults comes from comparison with the nodal planes of a normal fault earthquake at the trench that are parallel to the bend-faults (Figure $7 \mathrm{~b}$ ), and map in the center of the NW quadrant group of poles (Figure 11b). A deeper thrust earthquake (40 km depth from Harvard CMT catalog, $25 \mathrm{~km}$ from Engdahl et al. [1998]; $29 \mathrm{~km}$ from Tichelaar et al. [1992]; and 25-50 km from Honda et al. [1990]) located in the vicinity of the normal fault earthquake $(15 \mathrm{~km}$ depth from Harvard CMT catalog) shows nodal planes subparallel to the trench (Figure 7b). Apparently the normal fault earthquake is related to the deformation parallel to the Juan Fernández Ridge. Deeper in the incoming plate the deformation is decoupled.

\subsubsection{Fault Reactivation Hypothesis}

[34] In each of the study areas, patterns of nodal planes of near-trench earthquakes, bend-faults imaged in seismic data and the orientation of trench faults mapped with multibeam bathymetry are all similar to each other. Furthermore, the fault geometries mapped near the trench are also consistent with the nodal planes of intermediate-depth events in the corresponding slabs. The hypothesis of fault reactivation versus (new) fault generation during intermediate-depth earthquakes is supported by two distinct observations: (1) Changes in slab strike are not corresponded by changes in orientation of intermediate-depth focal mechanism that remain roughly parallel to the strike of trench bend faults. (2) Two conjugate sets of faults formed at large angles to each other at the trench correspond to the strike of nodal planes of intraslab events. One of the sets of faults is at large angle to the slab strike and thus to the predicted strike for newly formed rupture planes. This comparison of bendfault structure with intermediate-depth seismicity strongly supports the hypothesis that many intraslab earthquakes rupture preexisting weak zones formed by plate bending before subduction. 
[35] Both dehydration embrittlement and volume changes during the transition from gabbro/basalt to eclogite have been proposed to promote intraslab seismicity. However, studies of the young and hot Cascadia slab, where bend-faulting should be minor, show that eclogitization occurs without apparent association to intraslab seismicity [Brocher et al., 2003]. Thus, even though dehydration embrittlement and eclogitization may contribute to stresses in the slab leading to seismogenesis, preexisting weak and preferentially hydrated faults may be necessary to produce much of the observed intermediate-depth seismicity. In further support of this hypothesis, the intermediatedepth seismicity across the flat slab of central Chile, where slab pull should be small, indicates that possible dehydration reactions and water release at preexisting faults is sufficient to produce seismicity.

[36] The density of faulting in the incoming plate and the abundance of intermediate-depth seismicity in the slab also correlate qualitatively. The areas of pervasive near-trench faulting correspond downdip along the subducting plate to slabs with higher seismic activity, like along segments S4a and S4b of Middle America (Figure 4) and northern Chile (Figure 8). Similarly, the array of faults parallel to Juan Fernández Ridge, an area of anomalously intense bend-faulting in the Chile trench, projects downdip to an elongated cluster of intermediate-depth events near the southern end of the flat slab.

\subsection{Hydration of the Incoming Plate}

[37] There is a growing consensus that intermediate-depth seismicity is related to dehydration reactions during progressive metamorphism of the sinking slab [Meade and Jeanloz, 1991; Kirby et al., 1996; Peacock, 2001; Hacker et al., 2003; Husen et al., 2003]. The inference that much of the intermediate-depth seismicity in the study areas and elsewhere [e.g., Jiao et al., 2000] is consistent with reactivation of bend-faults has also implications for the hydration mechanisms of the oceanic lithosphere. The lithosphere consumed at most Circumpacific subduction zones was formed at fast spreading centers where most of the plate separation is taken up by magmatism while tectonism is comparatively minor. Fast spreading centers are characterized by shallow magma chambers [e.g., Detrick et al., 1993] that restrict faulting and vigorous hydrothermal circulation to the upper $\sim 2 \mathrm{~km}$ [Phipps Morgan et al., 1994; Ranero et al., 1997a; Shen, 2002]. Crust and uppermost mantle hydrothermal circulation is believed to occur pervasively only at slowspreading centers where faulting cuts across the entire crust [Toomey et al., 1988; Ranero et al., 1997b] and the uppermost mantle can be locally serpentinized [Canales et al., 2000]. However, lithosphere formed at slow-spreading centers currently only subducts in a few short trenches like the Lesser Antilles and South Sandwich. Thus, for most subduction zones, even though bend-faulting may reactivate spreading-center fabrics, much of the hydration will occur at the trench when reactivated shallow faults, and new faults, grow to penetrate across the crust into the upper mantle [Ranero et al., 2003a; Ranero and Sallares, 2004].

[38] It has been proposed that hydration leading to intraslab seismicity may also occur intraplate, during hot spot magmatism [Seno and Yamanaka, 1996; Yamasaki and Seno, 2003]. However, Cocos Ridge subduction is associated with low intraslab seismicity, which implies little hydration of the plate by the Galapagos hot spot. In contrast, the predicted extension of the Juan Fernández Ridge on the slab is associated with abundant seismicity. The difference in seismicity between the subducted continuation of these ridges might be that some thick-crust ridges like Cocos Ridge bend little at the trench with little hydration occurring in that environment, leading to sparse shallow and deep seismicity. Conversely, bend-faults along the Juan Fernández Ridge probably cut $15-20 \mathrm{~km}$ into the lithosphere and are reactivated resulting in abundant seismicity. Thus water percolation during bending-related faulting may be the dominant hydration mechanism of plates prior to subduction.

\subsection{Fault Reactivation and State of Stress in the Slab Below the Coupled Zone}

[39] The reactivation of preexisting faults during intraslab earthquakes seems to be independent of the state of stress in the slab (downdip compression or extension) and faults are not always reactivated with the same sense of motion (normal faulting) with which they originated in the outer-rise/near-trench region. In Central America and north Chile, downdip from the coupled zone, the state of stress of the slab is downdip extension (Figure 2). In these areas the predominant mechanism of the (rotated) intraslab earthquakes 

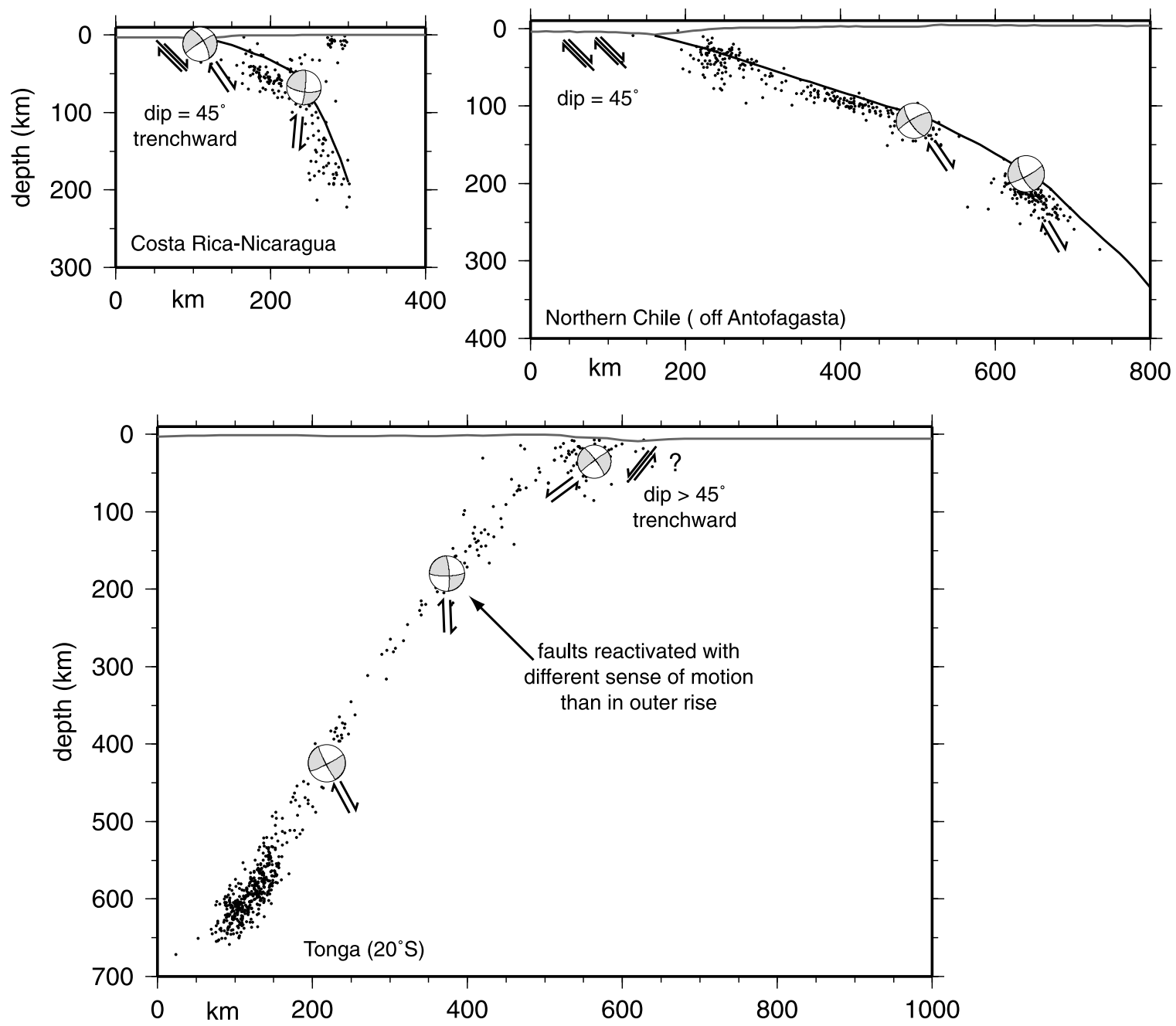

Figure 12. Cross sections of Middle America, northern Chile, and Tonga subduction zones showing near-trench faulting, slab geometry, and fault plane solutions of selected intraslab events. Arrows indicate movement along the nodal plane inferred to be the fault plane. In the Middle America Trench, fault planes have been imaged in seismic data [Ranero et al., 2003a]. In the northern Chile trench, fault planes are inferred from bathymetry. In the Tonga cross section, fault planes are those inferred by Jiao et al. [2000]. Note the change in fault dip with respect to the surface as the plate changes dip into the subduction zone. Normal faults formed during plate bending near the trench are reactivated with the same mechanism in the slabs of Middle America and northern Chile, but with an opposite sense of motion in Tonga slab.

is normal faulting, coincident with the mechanism of the trench events. Fault planes have been imaged with seismic data in the Middle America Trench [Ranero et al., 2003a] and inferred from bathymetry in the north Chile trench. In these regions the preexisting faults in the oceanic plate are being reactivated with the same sense of motion (Figure 12). In Tonga, however, the predominant state of stress in the slab is downdip compression but, as suggested by Jiao et al. [2000], intraslab earthquakes occur in the preexisting faults that were formed in an extensional (bending) setting in the outer rise. As a result, these preexisting normal faults are being reactivated as reverse faults (Figure 12).

\section{A Conceptual Model}

[40] Figure 13 shows our conceptual summary envisioned for subducting plates with pervasive bend-faulting and may not apply to subduction of young lithosphere, and broad aseismic ridges. The processes that occur with depth are as follows: (1) Oceanic plates approaching a subduction zones contain a hydrated and faulted upper crust, but the 


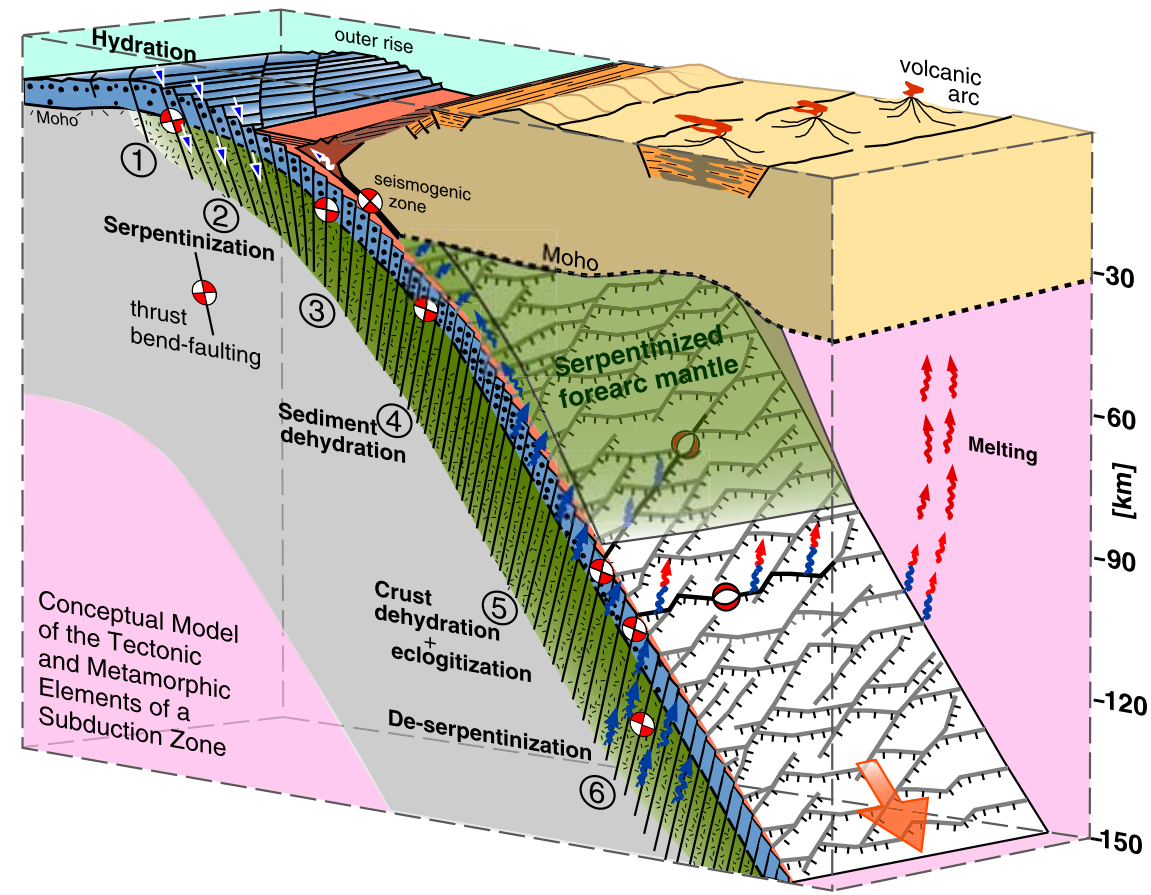

Figure 13. Cartoon showing a conceptual model of the structure and metamorphic evolution of subducting lithosphere formed at a fast spreading center. The topography of the plate in the outer-rise/trench region has been exaggerated to show better the deformation associated to plate bending. Scale is approximate everywhere else. Fault plane solutions of earthquakes are projected into the top of the slab and the plane of the cross section. Black filled circles in oceanic crust indicate hydration. See section 6 for discussion of model.

lower crust and mantle are comparatively undeformed and dry. (2) At the trench, extensional bend-faulting leads to partial hydration of the upper $\sim 20 \mathrm{~km}$ of the incoming plate [Ranero et al., 2003a; Ranero and Sallares, 2004]. Deeper thrust faults do not reach shallow levels and faults are not hydrated, and may not be reactivated as intraslab events. (3) Plate bending and faulting continues underneath the overriding plate [Mikumo et al., 2002; Vallée et al., 2003] and hydration might still be active there. (4) Progressive metamorphism dehydrates most of the water chemically bound in subducting sediment [Ruepke et al., 2002] leading to upper plate mantle hydration [Walther et al., 2000; ANCORP Working Group, 1999]. (5) Intraslab seismicity initiates between $\sim 60-80 \mathrm{~km}$ when dehydration of the oceanic crust [Ruepke et al., 2002; Hacker et al., 2003] leads to reactivation of the upper segment of bend-faults and earthquakes concentrate in the upper part of the slab [Bock et al., 2000; Yuan et al., 2000]. (6) Deeper than $\sim 100 \mathrm{~km}$ eclogitization is completed [Hacker et al., 2003]. At similar depths or slightly deeper the slab mantle dehydrates [Ruepke et al., 2002] and bend-faults will be reactivated producing seismicity within the upper slab mantle [Tibi et al., 2002;
Bock et al., 2000; Yuan et al., 2000]. There, fluids may reach the mantle wedge at the appropriate temperatures to produce partial melting leading to arc volcanism. If mantle dehydration starts at depths where eclogitization is not completed it may lead to a double seismic zone [Comte et al., 1999].

\section{Conclusions}

[41] The observations described above lead to several conclusions regarding the deformation of oceanic plates during bending, the relationships between bend-faulting and intraslab seismicity and the hydration of oceanic plates.

[42] 1. Bending-related deformation at trenches involves a complex faulting structure that seems to be mainly controlled by the relative orientation of the tectonic fabric formed at the paleo-spreading center with the axis of bending, by crustal thickness, and possibly by the presence of preexisting weak zones caused by lithospheric deformation linked to hot spot magmatism. The style of deformation of the incoming plate may dramatically change over along-strike distances of several hun- 
dred kilometers or even less along a subduction zone.

[43] 2. Patterns of orientation of the nodal planes of intermediate-depth earthquakes show a close similarity to patterns of faulting formed during plate bending and to near-trench bending-related earthquakes. These results strongly support that for the studied areas much of the intermediate-depth seismicity reactivates faults formed during plate bending near the trench.

[44] 3. Bend-faulting at trenches may be the prime mechanism for water percolation into the crust and upper mantle leading to mineral alteration and chemical hydration of subducting plates. The lack of intermediate-depth seismicity related to the subduction of the thick-crust Cocos Ridge formed at the Galapagos hot spot supports the inference that most of the hydration of incoming ocean plates occurs near the trench rather than being associated with hot spot magmatism.

\section{Appendix A: Data}

[45] To test the hypothesis of fault reactivation during intermediate-depth earthquakes, we use a 3 step approach: (1) Characterize deformation related to bending of the oceanic plate as it approaches the trench, mapping strike and dip of fault patterns. (2) Use databases of reliable earthquake focal mechanisms and earthquake locations (particularly focal depths). This allows to identify outer-rise (bending) events, discriminate between intraslab events and interplate (subduction) earthquakes and upper plate (crustal) events. (3) Determine the geometry of the top of the subducting slab from seismicity, global tomographic images and wide-angle seismic data in order to compare the local orientation of focal mechanisms of intraslab earthquakes relative to the slab.

[46] The following data sets were used for this study.

\section{A1. High-Resolution Multibeam Bathymetry}

[47] We use high-resolution multibeam bathymetry to map the pattern of faulting of the incoming plate to statistically characterize fault populations.

\section{A2. Multichannel Seismic Reflection}

[48] Where available, multichannel seismic reflection profiles (MCS) are used to image the faults in the oceanic plate [Ranero et al., 2003a]. Bathymetry alone can only resolve the dip of large faults, because scarps are usually modified by sediment mass wasting.

\section{A3. Velocity Models}

[49] We have compiled 2D wide-angle profiles to define the top of the subducting plate to depths of $\sim 40 \mathrm{~km}$ [Ye et al., 1996; Stavenhagen et al., 1998; Walther et al., 2000; Sallares et al., 2001; Berhorst et al., 2002]. At greater depths we use global travel time tomography models [Villaseñor et al., 2003] which are particularly suited to image subducted slabs, and which have a fine cell parameterization in regions of high seismicity and dense seismic networks. These tomographic models can also image the slabs in areas of seismic activity gaps and below the deepest seismicity.

\section{A4. Catalogs of Earthquake Locations}

[50] We use the database of teleseismic relocations of Engdahl et al. [1998], hereafter referred to as EHB. It consists of a subset of well-located earthquakes from the International Seismological Centre (ISC) and the USGS's National Earthquake Information Centre (NEIC) catalogs. The locations in the EHB data set represent a significant improvement relative to previous teleseismic locations due to the use of: improved theoretical travel times; ellipticity, bounce-point, station and topographic corrections; and S phases and (reidentified) depth phases. As a result of this location procedure, most of the earthquakes $(75 \%)$ in the EHB catalog are located better than $15 \mathrm{~km}$ in epicenter, and the uncertainty in depth is $35 \mathrm{~km}$ or smaller (depending on the presence of close stations and the availability of depth phases). For this study we use an upgraded and extended version from year 1964 to 2004 of the original EHB data set (E. R. Engdahl, personal communication).

\section{A5. Catalogs of Focal Mechanisms}

[51] We use the earthquake focal mechanisms from the Harvard centroid-moment tensor (CMT) cata$\log$ [Dziewonski et al., 1981; Dziewonski and Woodhouse, 1983], which currently extends from 1977 to 2004. This database of source mechanisms has been obtained in a consistent manner by waveform inversion of long period body and surface waves. The catalog is complete to approximately magnitude 5.5, with many smaller events also included. To preserve the relatively homogeneous character of the Harvard CMT catalog, no 
individual focal mechanism studies of outer-rise or intraslab earthquakes were included in our study.

[52] From the entire Harvard CMT catalog we have selected well-constrained focal mechanisms using the criteria proposed by Frohlich and Davis [1999]. These criteria are based on three statistical parameters: (1) the relative error $E_{r e l}$, which is the ratio of the scalar moment of the reported error tensor normalized by the moment tensor itself; (2) $f_{C L V D}$, which is a measure of the strength of the non-double couple component of the moment tensor; and $n_{\text {free }}$, the number of elements not fixed at zero during the inversion (if no element was fixed then $n_{\text {free }}=6$ ). The actual criteria used are: $E_{\text {rel }} \leq 0.15,\left|f_{C L V D}\right| \leq 0.20$, and $n_{\text {free }}=6$.

[53] The mechanisms selected using these criteria have $\mathrm{T}, \mathrm{B}$, and $\mathrm{P}$ axes with uncertainties of 510 degrees or less in their azimuth and plunge angles, and these uncertainties also apply to the azimuth and plunge of the nodal plane poles (C. Frohlich, personal communication). The application of these criteria results in a reduction of half of the CMT catalog.

\section{Appendix B: Methodology}

[54] The first goal of this study is to characterize faulting patterns of the incoming oceanic plate. Using the multibeam bathymetry we identify faulting systems associated with bending in the oceanic plate. The different populations of faults are then digitized, in order to measure their orientations (strikes). In addition, we use MCS profiles (where available) to determine the dip of bend-faults.

[55] Combining fault strikes with the fault dips we determine the poles of these faults, which can be compared with the poles from near-trench focal mechanisms from the Harvard CMT catalog. In many cases it is not possible to identify which of the two nodal planes of a focal mechanism is the actual fault plane. Therefore, for each mechanism we have two possible poles: one pole is normal to the fault plane, and the second pole is normal to the auxiliary plane and corresponds to the slip vector. The comparison of the poles from the observed faults can be used to confirm that the near-trench earthquakes are occurring in the mapped faults, and also to identify the correct fault plane from the two nodal plane possibilities. Throughout this article these comparisons are done using lower-hemisphere polar projections of the fault poles.
[56] In addition, we follow the approach of Jiao et al. [2000] to compare the mechanisms of outer-rise events with those of deep intraslab deep earthquakes (h $>70 \mathrm{~km}$ ). We first plot the poles of nodal planes of earthquakes for different depth ranges, in order to identify significant changes in mechanism with depth, and to eliminate interplate subduction earthquakes or earthquakes that occur in the upper plate. For the areas analyzed in this study, all earthquakes deeper than $70 \mathrm{~km}$ have mechanisms that are consistent with the internal deformation of the slab under down-dip tension, independent of the interplate coupling in the subduction zone. To select bending-related events, we choose focal depth less than $30 \mathrm{~km}$, and relative proportion of normal mechanism greater than $80 \%$ [Frohlich, 1992].

[57] To verify that intermediate-depth earthquakes reactivate the same faults created by bending in the incoming plate, we restore the subducting slab and the focal mechanisms of intraslab earthquakes to the horizontal. For this, we mapped the top of the subducting slab. This is accomplished by combining the data sets listed in the previous section. To depths $<100 \mathrm{~km}$ the top of the slab is mapped using wide-angle profiles and seismicity located with dense local networks. The deeper parts of the slab are mapped using teleseismic earthquake locations from the updated EHB catalog and a global P wave tomographic model [Villaseñor et al., 2003]. In the upper $200 \mathrm{~km}$, seismicity occurs mainly in the top part of the high velocity anomalies associated with the subducting slab. Therefore it is simple to map the top of the slab by picking the top of the seismicity and of the high velocity anomalies. At greater depths the seismicity no longer occurs at the top of the high velocity anomalies, but in the interior of the slab. In addition, some slabs have very low seismicity and/or gaps over certain depth ranges, and in those locations the only information to map the slab is provided by the tomography. As a result, uncertainties in the slab geometry increase with depth.

[58] From the map of the top of the slab it is possible to evaluate the local dip of the slab for each earthquake and rotate it to the horizontal. The $3 \mathrm{D}$ rotation of the focal mechanisms is carried out using Euler angles. The earthquake focal mechanisms used are from the Harvard CMT catalog, both for near-trench and intermediate-depth events. Each mechanism is associated with its corresponding EHB teleseismic relocation since 
these are the coordinates used to evaluate the slab dip.

[59] Finally, Fisher statistics [Fisher, 1953] are used to determine the mean directions and the uncertainties of the distribution of nodal plane poles. A Fisher distribution is the spherical analog of the normal distribution, and was developed for assessing dispersion of unit vectors on a sphere. In addition to the azimuth and plunge of the mean direction of the distribution, Fisher statistics also provide parameters that give information about the dispersion and randomness of the vector data. The parameter with a more evident physical meaning is $\alpha_{95}$, the radius in degrees of the circle of $95 \%$ confidence about the mean. Other parameters are randomness $R$, and precision $\kappa$. For less scattered data $R$ will approach $N$ (number of samples) and $\kappa$ tends to $\infty$.

\section{Acknowledgments}

[60] Bob Engdahl kindly provided the updated version of his earthquake relocations. We thank Fátima Martín-Hernández for help with the statistical analysis. The bathymetric data from Middle America were collected during R/V SONNE cruises 76, 81, 107, 144, 150, 163, and 173 and R/V M. Ewing cruises 0005 and 0104 . The bathymetric data from Chile were collected during SONNE cruises 101, 102, 103, 104, and 161. Figures were made with GMT software [Wessel and Smith, 1998]. A. Villaseñor was supported by ISES (Netherlands Research Center for Integrated Solid Earth Science) and by Sonderforschungsbereich 574 (SFB574) of University of Kiel during his visits to GEOMAR to work on this project. This is SFB574 contribution 74.

\section{References}

ANCORP Working Group (1999), Seismic reflection image revealing offset of Andean subduction-zone earthquake locations into oceanic mantle, Nature, 397, 341-344.

Barckhausen, U., C. R. Ranero, R. von Huene, S. C. Cande, and H. A. Roeser (2001), Revised tectonic boundaries in the Cocos Plate off Costa Rica: Implications for the segmentation of the convergent margin and for plate tectonic models, J. Geophys. Res., 106, 19,207-19,220.

Berhorst, A., E. R. Flueh, K. D. McIntosh, C. R. Ranero, I. Ahmed, E. Silver, and W. Strauch (2002), The crustal structure of the convergent Nicaraguan margin from a combined reflection and refraction study, Eos Trans. $A G U, 83(47)$, Fall Meet. Suppl., Abstract T62B-1311.

Bock, G., B. Schurr, and G. Asch (2000), High-resolution image of oceanic Moho in the subducting Nazca plate from P-S converted waves, Geophys. Res. Lett., 27, 3929-3932.

Brocher, T. M., T. Parsons, A. M. Tréhu, C. M. Snelson, and M. A. Fisher (2003), Seismic evidence for widespread serpentinized forearc upper mantle along the Cascadia margin, Geology, 31, 267-270.
Brudzinski, M. R., and W. Chen (2005), Earthquakes and strain in subhorizontal slabs, J. Geophys. Res., 110, B08303, doi:10.1029/2004JB003470.

Cahill, T., and B. L. Isacks (1992), Seismicity and shape of the subducted Nazca plate, J. Geophys. Res., 97, 17,50317,529 .

Canales, J. P., R. Detrick, J. Lin, J. A. Collins, and D. R. Toomey (2000), Crustal and upper mantle seismic structure beneath the rift mountains and across a nontransform offset at the Mid-Atlantic Ridge $\left(35^{\circ} \mathrm{N}\right)$, J. Geophys. Res., 105, 2699-2719.

Carbotte, G. F., and K. C. Macdonald (1994), Comparison of the seafloor tectonic fabric at intermediate, fast, and super fast spreading ridges: Influence of spreading rate, plate motions, and ridge segmentation on fault patterns, J. Geophys. Res., 99, 13,609-13,631.

Chen, P., C. R. Bina, and E. A. Okal (2004), A global survey of stress orientations in subducting slabs as revealed by intermediate-depth earthquakes, Geophys. J. Int., 159, $721-$ 733.

Christova, C., and C. H. Scholz (2003), Stresses in the Vanuatu subducting slab: A test of two hypotheses, Geophys. Res. Lett., 30(15), 1790, doi:10.1029/2003GL017701.

Clague, D. A., R. T. Holcomb, J. M. Sinton, R. S. Detrick, and M. E. Torresan (1990), Pliocene and Pleistocene alkalic flood basalts on the seafloor north of the Hawaiian islands, Earth Planet. Sci. Lett., 98, 175-191.

Collot, J., B. Marcaillou, F. Sage, F. Michaud, W. Agudelo, P. Charvis, D. Graindorge, M. Gutscher, and G. Spence (2004), Are rupture zone limits of great subduction earthquakes controlled by upper plate structures? Evidence from multichannel seismic reflection data acquired across the northern Ecuador-southwest Colombia margin, J. Geophys. Res., 109, B11103, doi:10.1029/2004JB003060.

Comte, D., L. Dorbath, M. Pardo, T. Monfret, H. Haessler, L. Rivera, M. Frogneux, B. Glass, and C. Meneses (1999), A double-layered seismic zone in Arica, northern Chile, Geophys. Res. Lett., 26, 1965-1968.

Detrick, R. S., A. J. Harding, G. M. Kent, J. A. Orcutt, J. C. Mutter, and P. Buhl (1993), Seismic structure of the southern East Pacific Rise, Science, 259, 499-503.

Dziewonski, A. M., and J. H. Woodhouse (1983), An experiment in the systematic study of global seismicity: Centroid moment tensor solutions of 201 moderate and large earthquakes of 1981, J. Geophys. Res., 88, 3247-3271.

Dziewonski, A. M., T.-A. Chou, and J. H. Woodhouse (1981), Determination of earthquake source parameters from waveform data for studies of global and regional seismicity, J. Geophys. Res., 86, 2825-2852.

Engdahl, E. R., R. van der Hilst, and R. Buland (1998), Global teleseismic earthquake relocation with improved travel times and procedures for depth determination, Bull. Seismol. Soc. Am., 88, 722-743.

Fisher, R. A. (1953), Dispersion on a sphere, Proc. R. Soc. London, Ser. A, 217, 295-305.

Frohlich, C. (1989), The nature of deep-focus earthquakes, Annu. Rev. Earth Planet Sci., 17, 227-254.

Frohlich, C. (1992), Triangle diagrams: Ternary graphs to display similarity and diversity of earthquake focal mechanisms, Phys. Earth Planet. Inter., 75, 193-198.

Frohlich, C., and S. D. Davis (1999), How well constrained are well-constrained $\mathrm{T}, \mathrm{B}$, and $\mathrm{P}$ axes in moment tensor catalogs?, J. Geophys. Res., 104, 4901-4910.

Gripp, A. E., and R. G. Gordon (1990), Current plate velocities relative to the hotspots incorporating the NUVEL-1 global plate motion model, Geophys. Res. Lett., 17, 1109-1112. 
Hacker, B. R., S. M. Peacock, G. A. Abers, and S. D. Holloway (2003), Subduction factory: 2. Are intermediate-depth earthquakes in subducting slabs linked to metamorphic dehydration reactions?, J. Geophys. Res., 108(B1), 2030, doi:10.1029/ 2001JB001129.

Honda, S., H. Kawakatsu, and T. Seno (1990), Centroid depth of the October 1981 off Chile outer-rise earthquake (Ms = 7.2) determined by a comparison of several waveform inversion methods, Bull. Seismol. Soc. Am., 80, 69-87.

Husen, S., R. Quintero, E. Kissling, and B. Hacker (2003), Subduction-zone structure and magmatic processes beneath Costa Rica constrained by local earthquake tomography and petrologic modelling, Geophys. J. Int., 155, 11-32.

Jiao, W., P. G. Silver, Y. Fei, and C. T. Prewitt (2000), Do intermediate- and deep-focus earthquakes occur on preexisting weak zones? An examination of the Tonga subduction zone, J. Geophys. Res., 105, 28,125-28,138.

Kirby, S. H., E. R. Engdahl, and R. Denlinger (1996), Intermediate-depth intraslab earthquakes and arc volcanism as physical expressions of crustal and uppermost mantle metamorphism in subducting slabs, in Subduction: Top to Bottom, Geophys. Monogr. Ser., vol. 96, edited by G. E. Bebout et al., pp. 195-214, AGU, Washington, D. C.

Masson, D. G. (1991), Fault patterns at outer trench walls, Mar. Geophys. Res., 13, 209-225.

Meade, C., and R. Jeanloz (1991), Deep-focus earthquakes and recycling of water into the Earth's mantle, Science, 252, 6872 .

Mikumo, T., Y. Yagi, S. K. Singh, and M. A. Santoyo (2002), Coseismic and postseismic stress changes in a subducting plate: Possible stress interactions between large interplate thrust and intraplate normal-faulting earthquakes, J. Geophys. Res., 107(B1), 2023, doi:10.1029/2001JB000446.

Peacock, S. (1990), Fluid processes in subduction zones, Science, 248, 329-337.

Peacock, S. (2001), Are the lower planes of double seismic zones caused by serpentine dyhydration in subducting oceanic mantle?, Geology, 29, 299-302.

Phipps Morgan, J., A. Harding, J. Orcutt, G. Kent, and Y. J. Chen (1994), An observational and theoretical synthesis of magma chamber geometry and crustal genesis along a midocean ridge spreading center, in Magmatic Systems, edited by M. P. Ryan, pp. 139-178, Elsevier, New York.

Protti, M., F. Guendel, and K. McNally (1995), Correlation between the age of the subducting Cocos plate and the geometry of the Wadati-Benioff zone under Nicaragua and Costa Rica, Spec. Pap. Geol. Soc. Am., 295, 309-326.

Raleigh, C. B., and M. S. Paterson (1965), Experimental deformation of serpentinite and its tectonic implications, J. Geophys. Res., 70, 3965-3985.

Ranero, C. R., and V. Sallares (2004), Geophysical evidence for alteration of the crust and mantle of the Nazca Plate during bending at the north Chile trench, Geology, 32, $549-552$.

Ranero, C. R., T. J. Reston, I. Belykh, and H. Gnibidenko (1997a), Reflective oceanic crust formed at a fast-spreading center in the Pacific, Geology, 25, 499-502.

Ranero, C. R., E. Banda, and P. Buhl (1997b), The crustal structure of the Canary Basin: Accretion processes at slow spreading centers, J. Geophys. Res., 102, 10,185-10,201.

Ranero, C. R., J. Phipps Morgan, K. McIntosh, and C. Reichert (2003a), Bending, faulting, and mantle serpentinization at the Middle America trench, Nature, 425, 367-373.

Ranero, C. R., W. Weinrebe, L. Grevemeyer, J. Phipps Morgan, P. Vannucchi, and R. von Huene (2003b), Tectonic structure of the Middle America Pacific Margin and Incoming Cocos
Plate from Costa Rica to Guatemala, Eos Trans. $A G U$, 84(46), AGU Fall Meet., Abstract T52C-0289.

Ruepke, L. H., J. Phipps Morgan, M. Hort, and J. A. D. Connolly (2002), Are the regional variations in Central American arc lavas due to differing basaltic versus peridotitic slab sources of fluids?, Geology, 30, 1035-1038.

Sallares, V., J. J. Dañobeitia, and E. Flueh (2001), Lithospheric structure of the Costa Rica Isthmus: Effects of subduction zone magmatism on an oceanic plateau, J. Geophys. Res., $106,621-643$.

Savage, J. C. (1969), The mechanics of deep-focus faulting, Tectonophysics, 8, 115-127.

Seno, T., and Y. Yamanaka (1996), Double seismic zones, compressional deep trench-outer rise events, and superplumes, in Subduction: Top to Bottom, Geophys. Monogr. Ser., vol. 96, edited by G. E. Bebout et al., pp. 347-355, AGU, Washington, D. C.

Shen, Y. (2002), Seismicity at the southern East Pacific Rise from recordings of an ocean bottom seismometer array, J. Geophys. Res., 107(B12), 2368, doi:10.1029/ 2001JB001742.

Staudigel, H., T. Plank, B. White, and H. U. Schmincke (1996), Geochemical fluxes during alteration of the basaltic oceanic crust: DSDP sites 417 and 418, in Subduction: Top to Bottom, Geophys. Monogr. Ser., vol. 96, edited by G. E. Bebout et al., pp. 19-38, AGU, Washington, D. C.

Stavenhagen, A. U., et al. (1998), Seismic wide-angle investigations in Costa Rica-A transect from the Pacific to the Atlantic Coast across the Middle American Landbridge, Zentralblatt Geol. Paläontol., 3-6, 393-408.

Tibi, R., G. Bock, and C. H. Estabrook (2002), Seismic body wave constraint on mechanisms of intermediate-depth earthquakes, J. Geophys. Res., 107(B3), 2047, doi:10.1029/ 2001JB000361.

Tichelaar, B. W., D. H. Christensen, and L. J. Ruff (1992), Depth extent of rupture of the 1981 Chilean outer-rise earthquake as inferred from long-period body waves, Bull. Seismol. Soc. Am., 82, 1236-1252.

Toomey, D. R., S. C. Solomon, and G. M. Purdy (1988), Microearthquakes beneath the median valley of the Mid-Atlantic Ridge near $23^{\circ} \mathrm{N}$ : Tomography and tectonics, J. Geophys. Res., 93, 9093-9112.

Vallée, M., M. Bouchon, and S. Y. Schwartz (2003), The 13 January 2001 El Salvador earthquake: A multidata analysis, J. Geophys. Res., 108(B4), 2203, doi:10.1029/ 2002JB001922.

Villaseñor, A., W. Spakman, and E. R. Engdahl (2003), Influence of regional travel times in global tomographic models, paper presented at EGS-AGU-EUG Joint Assembly, Eur. Geophys. Soc., Nice, France, 6-11 April.

von Huene, R., and C. R. Ranero (2003), Subduction erosion and basal friction along the sediment-starved convergent margin off Antofagasta, Chile, J. Geophys. Res., 108(B2), 2079, doi:10.1029/2001JB001569.

von Huene, R., J. Corvalan, E. R. Flueh, K. Hinz, J. Korstgard, C. R. Ranero, W. Weinrebe, and CONDOR Scientists (1997), Tectonic control of the subducting Juan Fernández Ridge on the Andean margin near Valparaiso, Chile, Tectonics, 16, 474-488.

von Huene, R., C. R. Ranero, W. Weinrebe, and K. Hinz (2000), Quaternary convergent margin tectonics of Costa Rica, segmentation of the Cocos plate, and Central American volcanism, Tectonics, 19, 314-334.

Walther, C. H. E. (2003), The crustal structure of the Cocos ridge off Costa Rica, J. Geophys. Res., 108(B3), 2136, doi:10.1029/2001JB000888. 
Walther, C. H. E., E. R. Flueh, C. R. Ranero, R. von Huene, and W. Strauch (2000), Crustal structure across the Pacific margin of Nicaragua: Evidence for ophiolitic basement and a shallow mantle sliver, Geophys. J. Int., 141, 759-777.

Weinrebe, W., C. R. Ranero, J. Diaz, C. Reichert, and E. E. Vera (2003), Continental margin tectonics along the convergent plate boundary of central Chile, Eos Trans. $A G U$, 84(46), AGU Fall Meet., Abstract T31C-0859.

Werner, R., K. Hoernle, P. van den Bogaard, C. R. Ranero, R. von Huene, and D. Korich (1999), Drowned 14 m. y. old Galapagos archipelago off the coast of Costa Rica: Implications for tectonic and evolutionary models, Geology, 27, 499-502.

Wessel, P., and W. H. F. Smith (1998), New improved version of generic mapping tools released, Eos Trans. AGU, 79, 579.
Yamasaki, T., and T. Seno (2003), Double seismic zone and dehydration embrittlement of the subducting slab, J. Geophys. Res., 108(B4), 2212, doi:10.1029/2002JB001918.

Yáñez, G. A., C. R. Ranero, R. von Huene, and J. A. Díaz (2001), Tectonic interpretation of magnetic anomalies across a segment of the convergent margin of the southern Central Andes $\left(32^{\circ}-34^{\circ} \mathrm{S}\right)$, J. Geophys. Res., 106, 63256345.

Ye, S., J. Bialas, E. R. Flueh, A. Stavenhagen, R. von Huene, G. Leandro, and K. Hinz (1996), Crustal structure of the Middle American Trench off Costa Rica from wide-angle seismic data, Tectonics, 15, 1006-1021.

Yuan, X., et al. (2000), Subduction and collision processes in the Central Andes constrained by converted seismic phases, Nature, 408, 958-961. 